\title{
LEVEL II SCOUR ANALYSIS FOR BRIDGE 1 (JAY-TH00040001) on TOWN HIGHWAY 4, crossing CROOK BROOK, JAY, VERMONT
}

U.S. Geological Survey Open-File Report 97-366

Prepared in cooperation with

VERMONT AGENCY OF TRANSPORTATION and

FEDERAL HIGHWAY ADMINISTRATION 


\section{LEVEL II SCOUR ANALYSIS FOR BRIDGE 1 (JAY-TH00040001) on TOWN HIGHWAY 4, crossing CROOK BROOK, JAY, VERMONT By SCOTT A. OLSON}

U.S. Geological Survey Open-File Report 97-366

Prepared in cooperation with

VERMONT AGENCY OF TRANSPORTATION

and

FEDERAL HIGHWAY ADMINISTRATION 


\title{
U.S. DEPARTMENT OF THE INTERIOR BRUCE BABBITT, Secretary
}

\author{
U.S. GEOLOGICAL SURVEY \\ Gordon P. Eaton, Director
}

For additional information write to:

District Chief

U.S. Geological Survey 361 Commerce Way

Pembroke, NH 03275-3718
Copies of this report may be purchased from:

U.S. Geological Survey

Branch of Information Services

Open-File Reports Unit

Box 25286

Denver, CO 80225-0286 


\section{CONTENTS}

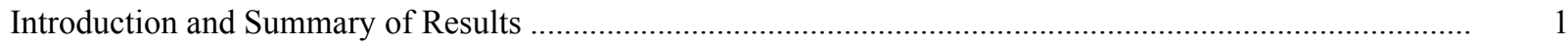

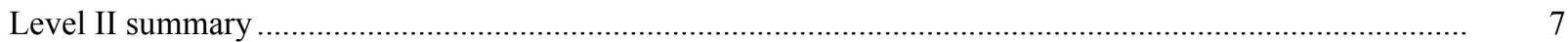

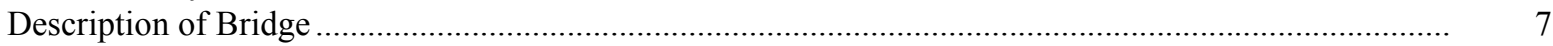

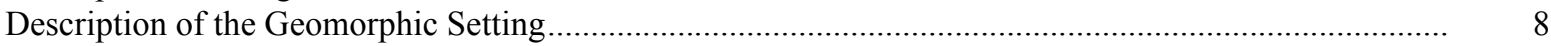

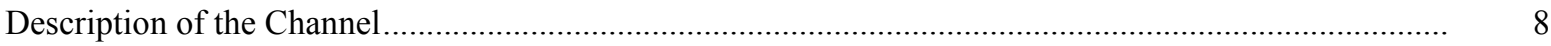

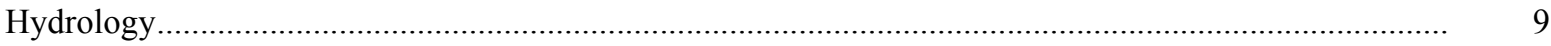

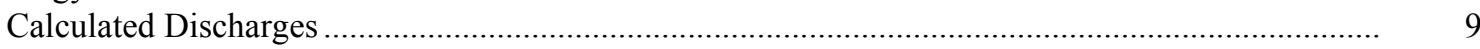

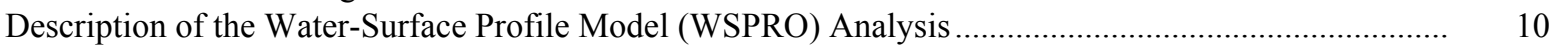

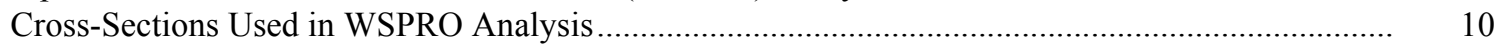

Data and Assumptions Used in WSPRO Model ..................................................................... 11

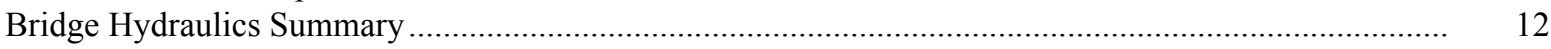

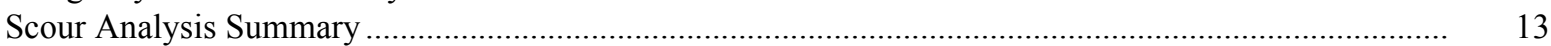

Special Conditions or Assumptions Made in Scour Analysis ...................................................... 13

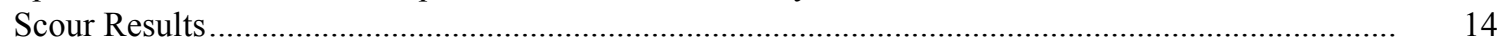

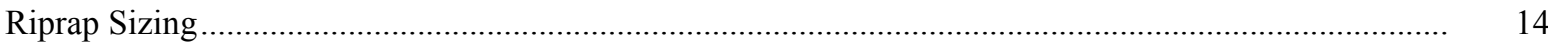

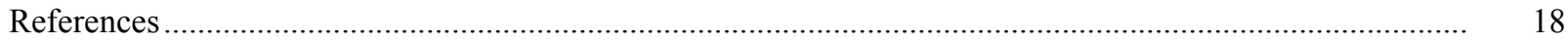

Appendixes:

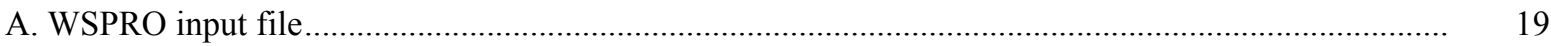

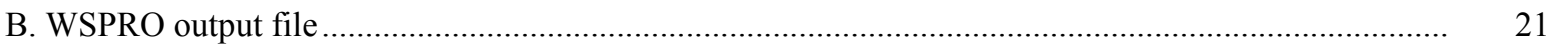

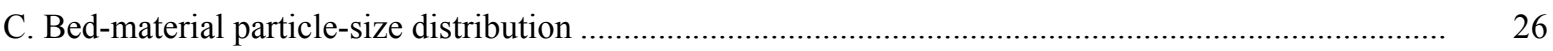

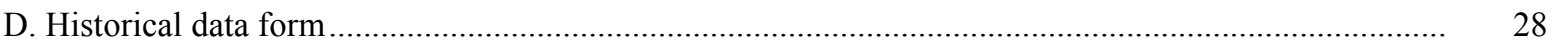

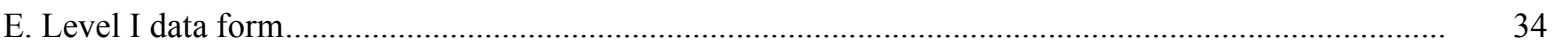

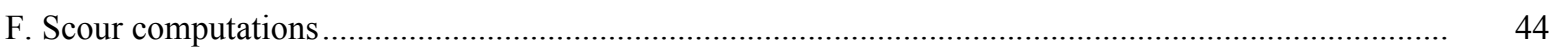

\section{FIGURES}

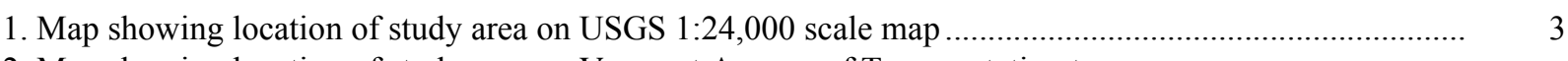

2. Map showing location of study area on Vermont Agency of Transportation town

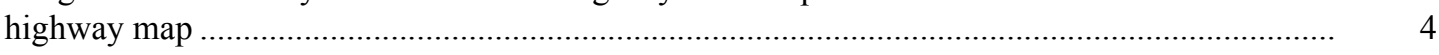

3. Structure JAY-TH00040001 viewed from upstream (June 5, 1995) ....................................................... 5

4. Downstream channel viewed from structure JAY-TH00040001 (June 5, 1995). ................................. 5

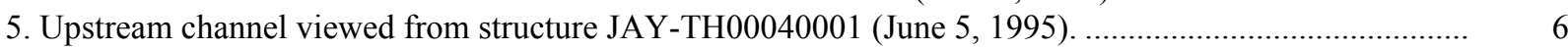

6. Structure JAY-TH00040001 viewed from downstream (June 5, 1995) ............................................. 6

7. Water-surface profiles for the 100- and 500-year discharges at structure

JAY-TH00040001 on Town Highway 4, crossing Crook Brook,

Jay, Vermont.

8. Scour elevations for the 100- and 500-year discharges at structure

JAY-TH00040001 on Town Highway 4, crossing Crook Brook,

Jay, Vermont.

\section{TABLES}

1. Remaining footing/pile depth at abutments for the 100-year discharge at structure

JAY-TH00040001 on Town Highway 4, crossing Crook Brook,

Jay, Vermont

2. Remaining footing/pile depth at abutments for the 500-year discharge at structure

JAY-TH00040001 on Town Highway 4, crossing Crook Brook,

Jay, Vermont 


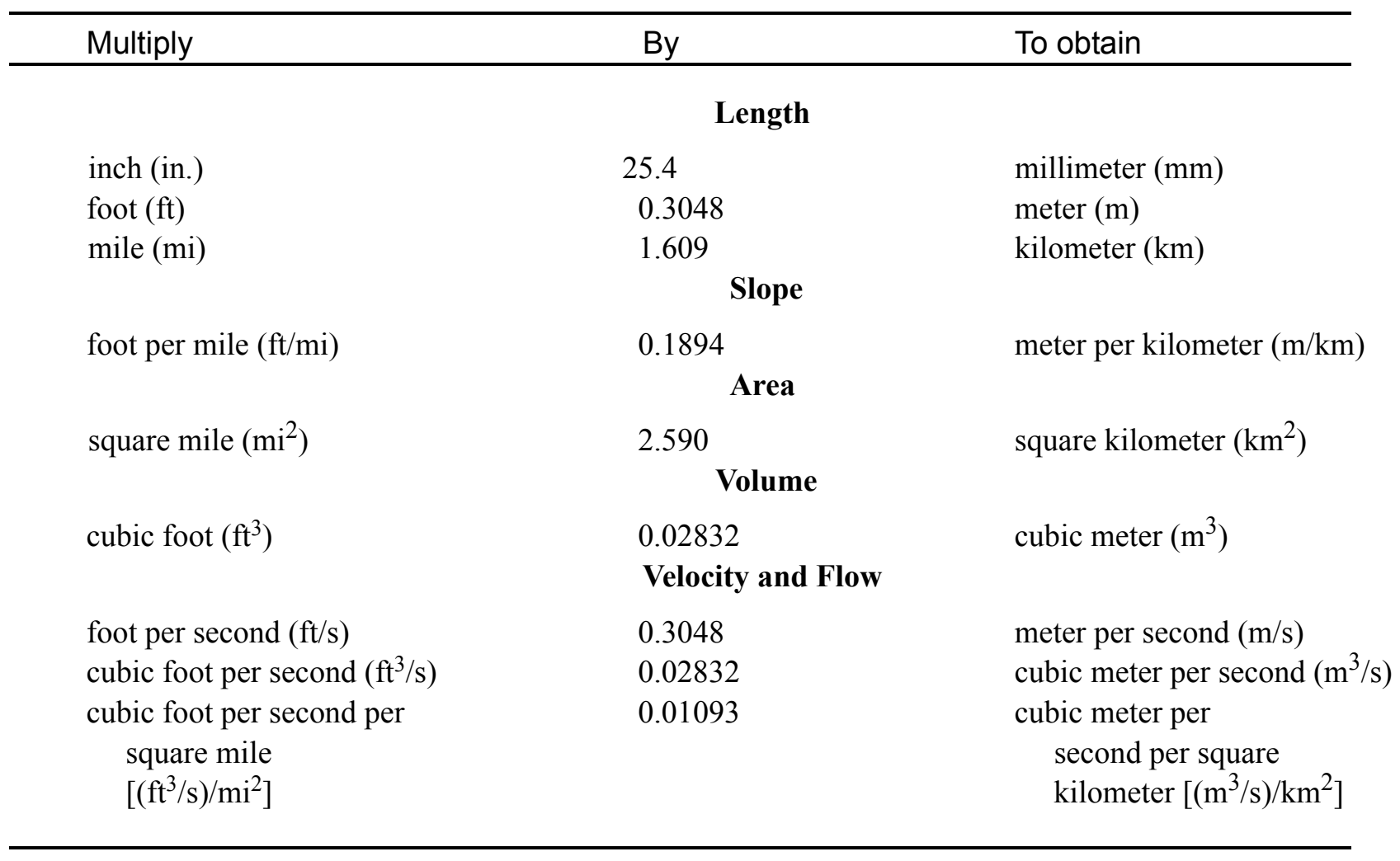

\section{OTHER ABBREVIATIONS}

$\begin{array}{lrlr}\mathrm{BF} & \text { bank full } & \text { LWW } & \text { left wingwall } \\ \mathrm{cfs} & \text { cubic feet per second } & \text { MC } & \text { main channel } \\ \mathrm{D}_{50} & \text { median diameter of bed material } & \text { RAB } & \text { right abutment } \\ \mathrm{DS} & \text { downstream } & \text { RABUT } & \text { face of right abutment } \\ \mathrm{elev} & \text { elevation } & \text { RB } & \text { right bank } \\ \mathrm{f} / \mathrm{p} & \text { flood plain } & \text { ROB } & \text { right overbank } \\ \mathrm{ft}^{2} & \text { square feet } & \text { RWW } & \text { right wingwall } \\ \mathrm{ft} / \mathrm{ft} & \text { feet per foot } & \text { TH } & \text { town highway } \\ \mathrm{JCT} & \text { junction } & \text { UB } & \text { under bridge } \\ \mathrm{LAB} & \text { left abutment } & \text { US } & \text { upstream } \\ \mathrm{LABUT} & \text { face of left abutment } & \text { USGS } & \text { United States Geological Survey } \\ \mathrm{LB} & \text { left bank } & \text { VTAOT Vermont Agency of Transportation } \\ \mathrm{LOB} & \text { left overbank } & \text { WSPRO } & \text { water-surface profile model }\end{array}$

In this report, the words "right" and "left" refer to directions that would be reported by an observer facing downstream. Sea level: In this report, "sea level" refers to the National Geodetic Vertical Datum of 1929-- a geodetic datum derived from a general adjustment of the first-order level nets of the United States and Canada, formerly called Sea Level Datum of 1929.

In the appendices, the above abbreviations may be combined. For example, USLB would represent upstream left bank. 


\title{
LEVEL II SCOUR ANALYSIS FOR BRIDGE 1 (JAY-TH00040001) ON TOWN HIGHWAY 4, CROSSING CROOK BROOK, JAY, VERMONT
}

\author{
By Scott A. Olson
}

\section{INTRODUCTION AND SUMMARY OF RESULTS}

This report provides the results of a detailed Level II analysis of scour potential at structure JAY-TH00040001 on Town Highway 4 crossing Crook Brook, Jay, Vermont (figures 1-8). A Level II study is a basic engineering analysis of the site, including a quantitative analysis of stream stability and scour (U.S. Department of Transportation, 1993). Results of a Level I scour investigation also are included in Appendix $\mathrm{E}$ of this report. A Level I investigation provides a qualitative geomorphic characterization of the study site. Information on the bridge, gleaned from Vermont Agency of Transportation (VTAOT) files, was compiled prior to conducting Level I and Level II analyses and is found in Appendix D.

The site is in the Green Mountain section of the New England physiographic province in northern Vermont. The $20.7-\mathrm{mi}^{2}$ drainage area is in a predominantly rural and forested basin. In the vicinity of the study site, the surface cover is thick woody vegetation and/or forest except for the upstream right bank and overbank which is pasture.

In the study area, Crook Brook has an incised, sinuous channel with a slope of approximately $0.02 \mathrm{ft} / \mathrm{ft}$, an average channel top width of $86 \mathrm{ft}$ and an average bank height of $6 \mathrm{ft}$. The channel bed material ranges from gravel to boulder with a median grain size $\left(\mathrm{D}_{50}\right)$ of $48.7 \mathrm{~mm}(0.160 \mathrm{ft})$. The geomorphic assessment at the time of the Level I and Level II site visit on June 5, 1995, indicated that the reach was stable.

The Town Highway 4 crossing of Crook Brook is a 49-ft-long, two-lane bridge consisting of one 45-foot concrete span (Vermont Agency of Transportation, written communication, March 6, 1995). The opening length of the structure parallel to the bridge face is $42 \mathrm{ft}$.The bridge is supported by vertical, concrete abutments with wingwalls. The channel is skewed approximately 5 degrees to the opening. The opening-skew-to-roadway is also 5 degrees.

Channel scour is present along the left abutment. The scoured area was $1.5 \mathrm{ft}$ deeper than the mean thalweg depth during the Level I assessment. Scour countermeasures include type-2 stone fill (less than 36 inches diameter) on the upstream and downstream sides of the left road embankment and at the upstream end of the left abutment. There is type-3 stone fill (less than 48 inches diameter) along the base of the upstream left wingwall. Additional details describing conditions at the site are included in the Level II Summary and Appendices D and $\mathrm{E}$. 
Scour depths and recommended rock rip-rap sizes were computed using the general guidelines described in Hydraulic Engineering Circular 18 (Richardson and others, 1995). Total scour at a highway crossing is comprised of three components: 1) long-term streambed degradation; 2) contraction scour (due to accelerated flow caused by a reduction in flow area at a bridge) and; 3 ) local scour (caused by accelerated flow around piers and abutments). Total scour is the sum of the three components. Equations are available to compute depths for contraction and local scour and a summary of the results of these computations follows.

Contraction scour for all modelled flows ranged from 2.5 to $3.8 \mathrm{ft}$. The worst-case contraction scour occurred at the 500-year discharge. Abutment scour at the left abutment ranged from 15.4 to $18.5 \mathrm{ft}$. Abutment scour at the right abutment ranged from 12.3 to 15.3 $\mathrm{ft}$. The worst-case abutment scour occurred at the 500-year discharge for both abutments. Additional information on scour depths and depths to armoring are included in the section titled "Scour Results". Scoured-streambed elevations, based on the calculated scour depths, are presented in tables 1 and 2. A cross-section of the scour computed at the bridge is presented in figure 8 . Scour depths were calculated assuming an infinite depth of erosive material and a homogeneous particle-size distribution.

It is generally accepted that the Froehlich equation (abutment scour) gives "excessively conservative estimates of scour depths" (Richardson and others, 1995, p. 47). Usually, computed scour depths are evaluated in combination with other information including (but not limited to) historical performance during flood events, the geomorphic stability assessment, existing scour protection measures, and the results of the hydraulic analyses. Therefore, scour depths adopted by VTAOT may differ from the computed values documented herein. 


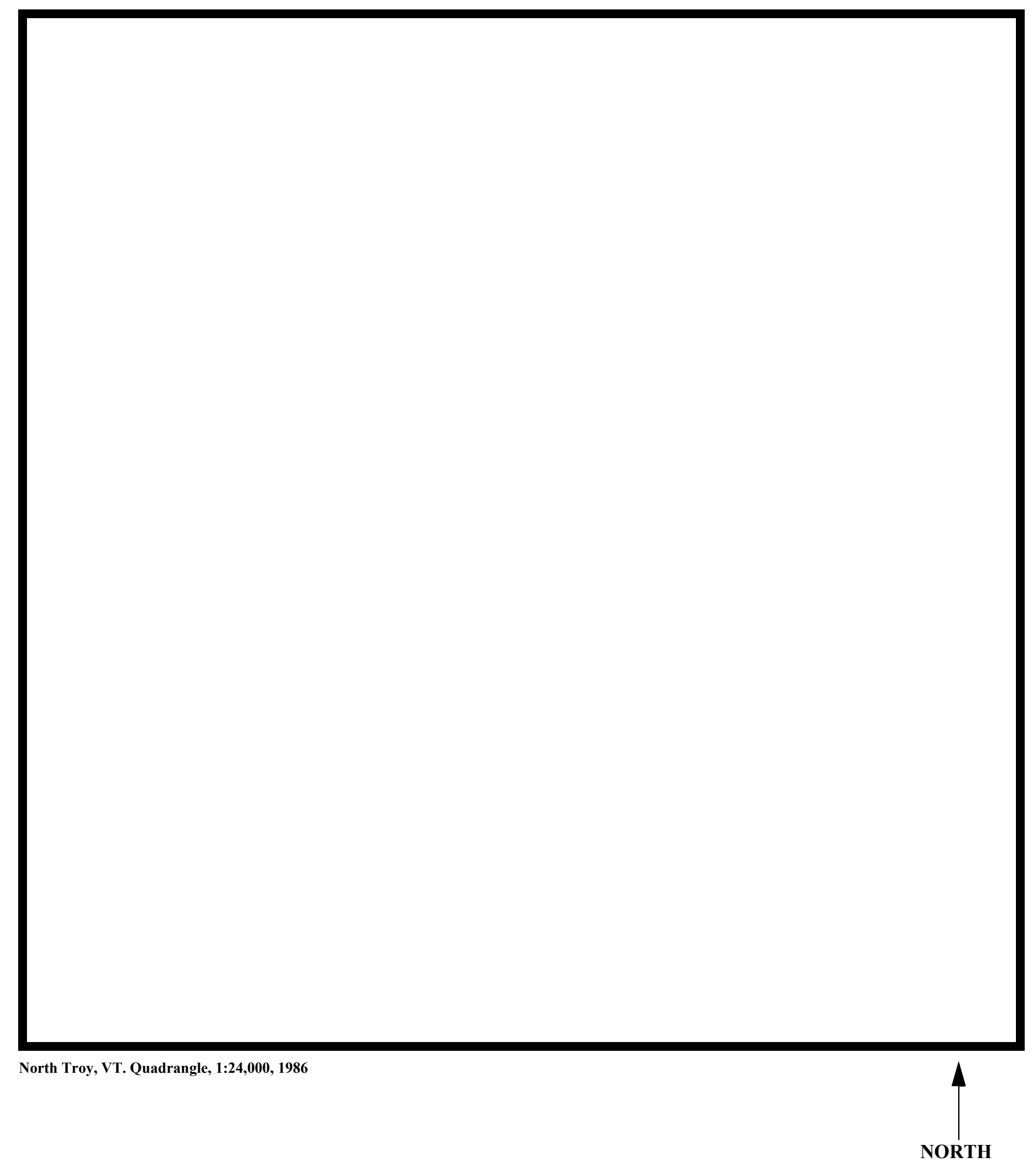

Figure 1. Location of study area on USGS 1:24,000 scale map. 
Figure 2. Location of study area on Vermont Agency of Transportation town highway map. 

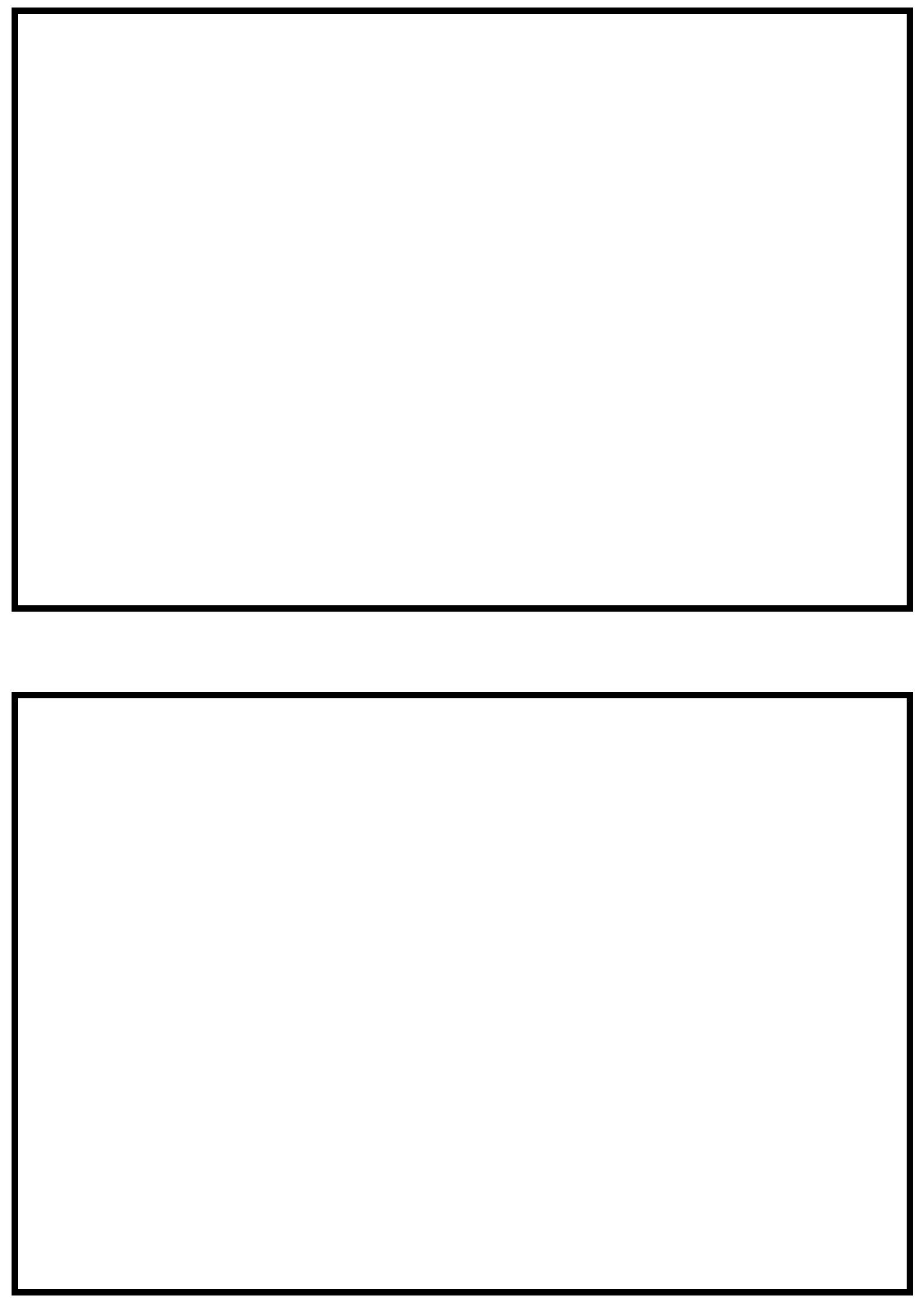

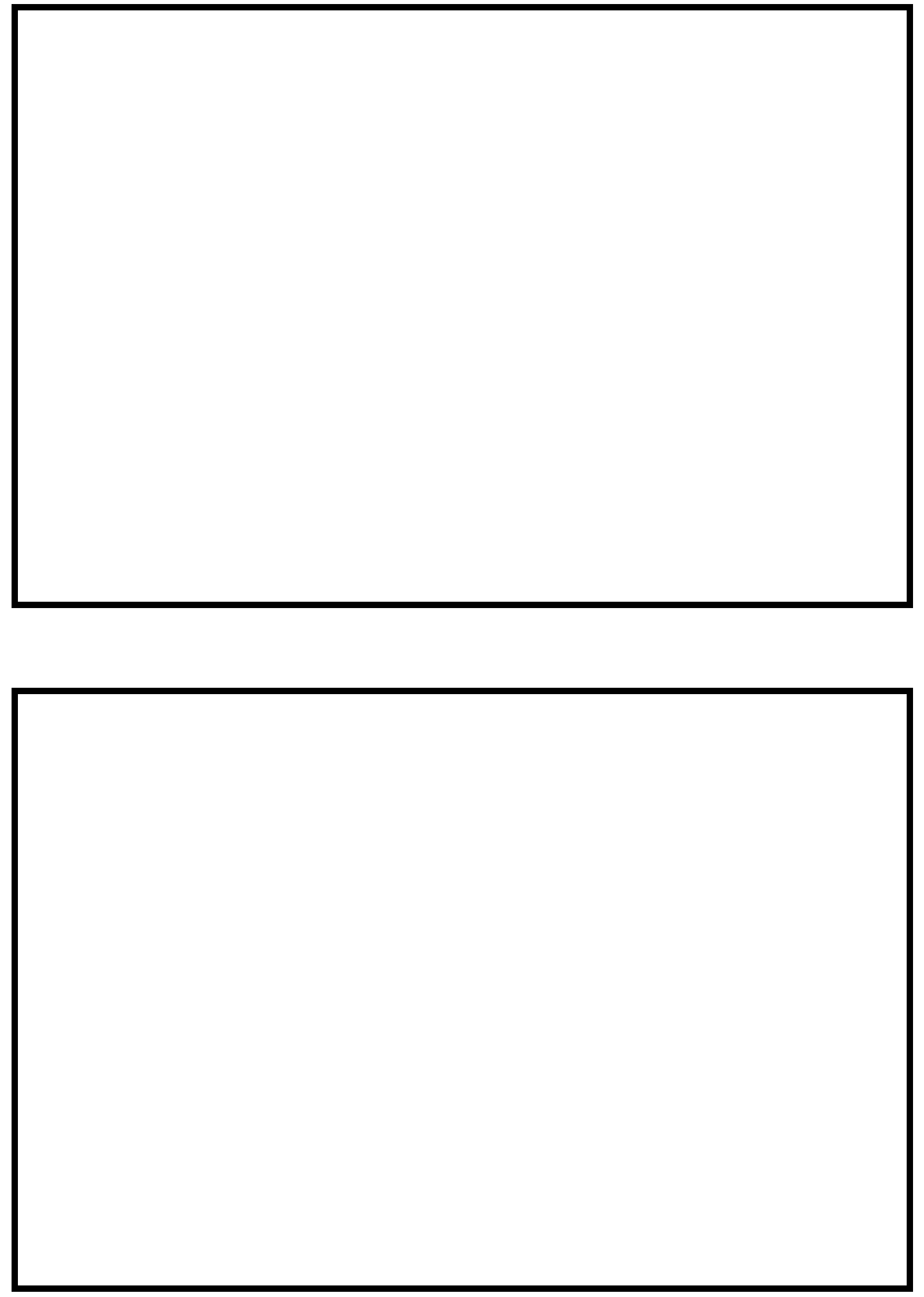


\section{LEVEL II SUMMARY}

\begin{tabular}{lllllll} 
& \multirow{2}{*}{ Structure Number } & JAY-TH00040001 & Stream & \multicolumn{3}{c}{ Crook Brook } \\
& Orleans & Road & TH4 & District & 9
\end{tabular}

\section{Description of Bridge}

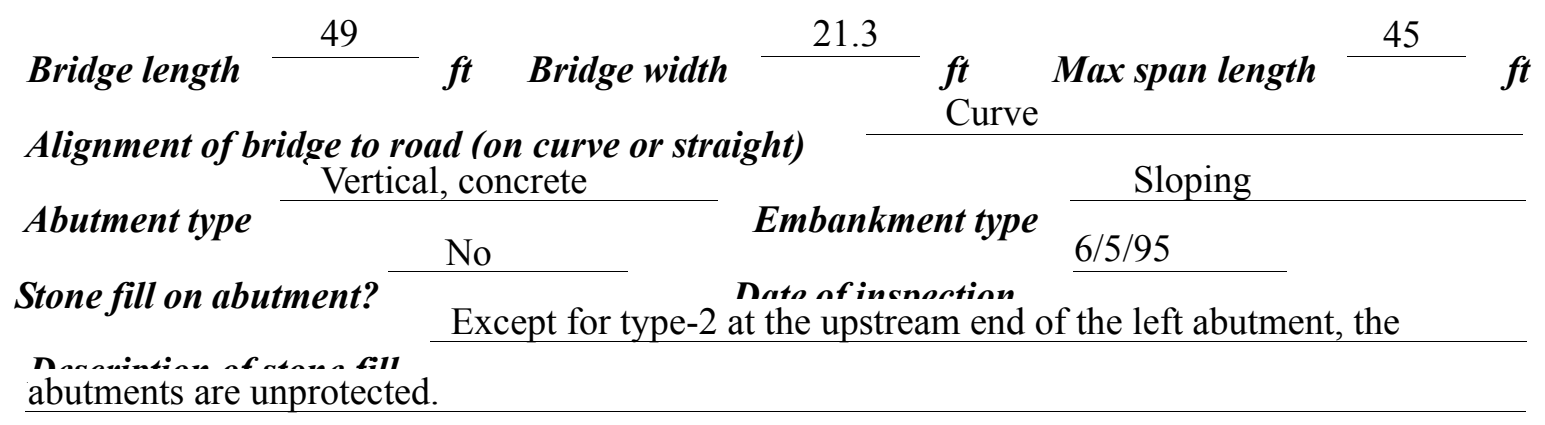

Abutments and wingwalls are concrete. The left

abutment is in a channel impact zone and has a subfooter along its toe.

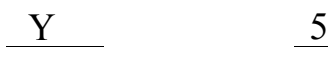

Is bridge skewed to flood flow according to Y ' survey? Angle left abutment. There is scour along the left abutment in this impact zone.

Debris accumulation on bridge at time of Level I or Level II site visit:

\begin{tabular}{|c|c|c|c|}
\hline & $\begin{array}{c}\text { Date of incnortion } \\
\underline{6 / 5 / 95}\end{array}$ & $\begin{array}{l}\text { Percent of almmual } \\
\text { blocked inortzontatly }\end{array}$ & $\begin{array}{l}\text { Percent of } 0 \\
\text { blocked verticatty }\end{array}$ \\
\hline vel I & $6 / 5 / 95$ & 0 & 0 \\
\hline el II & Low. & & \\
\hline
\end{tabular}

\section{Potential for debris}

June 5, 1995. There is a island 150 feet downstream of the bridge. The island is approximately Doscriho anv, foaturos noar ar at tho hridoo that mave affort flow, (includo ahsorvation dato) one-third the channel width. Flow on either side of the island is roughly the same. 


\section{Description of the Geomorphic Setting}

General topography The channel is located within a narrow upland valley with no flood plains. $6 / 5 / 95$

Geomorphic conditions at bridge site: downstream (DS), upstream (US)

Date of inspection Moderately

DS left: $\quad$ sloped overbank.

DS right: $\quad$ Moderately sloped overbank.

US left: $\quad$ Moderately sloped overbank.

US right: $\quad$ Moderately sloped overbank.

\section{Description of the Channel}

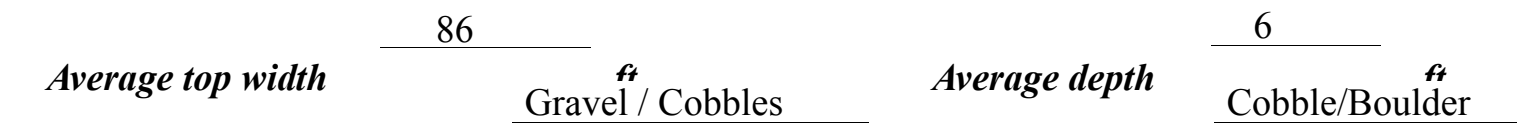

Predominant bed material Bank material Sinuous but stable.

Incised with non-alluvial channel boundaries and a no flood pläins."

$6 / 5 / 95$

Vegetative co ${ }^{1}$ Forest.

DS left: $\quad$ Forest.

DS right: $\quad$ Brush and forest.

US left: $\quad$ Pasture with a few trees.

US right: $\quad \underline{\mathrm{Y}}$

Do banks appear stable? -

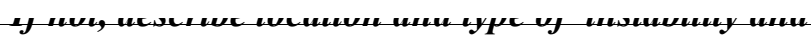
date of observatton.

an island 150 feet downstream of the bridge. The island is approximately one-third the channel Describe any obstructions in channel and date of observation. width. Flow on either side of the island is roughly the same. 


\title{
Hydrology
}

Drainage area $\stackrel{20.7}{m_{i}{ }^{2}}$

Percentage of drainage area in physiographic provinces: (approximate)

Physiographic province/section

New England/Green Mountain
Percent of drainage area 100

\begin{abstract}
Is drainage area considered rural or urban?
Rural None.

urbanization:

Describe any significant
\end{abstract}

Is there a USGS gage on the stream of interest?

No

USGS gage description

USGS gage number

Gage drainage area $\mathrm{mi}^{2}$

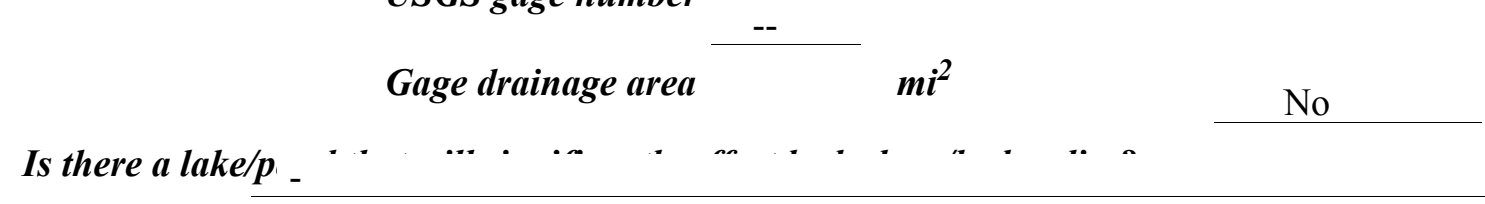

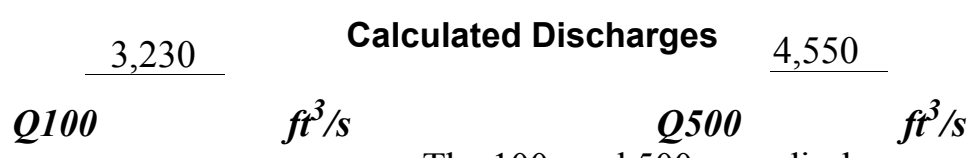

The 100- and 500-year discharges were computed

using methods described in "Peak rates of runoff in the New England Hill and Lowland area" (Potter, $1957 \mathrm{~b}$ ) and graphically extrapolated to the 500-year discharge. These results were chosen due to their central tendency (within 10 per cent of the average) among other empirical techniques applicable to a drainage with basin characteristics similar to the ones at this site (Benson, 1962; Johnson and Tasker, 1974; FHWA, 1983; Talbot, 1887). 


\section{Description of the Water-Surface Profile Model (WSPRO) Analysis}

Datum for WSPRO analysis (USGS survey, sea level, VTAOT plans)

USGS survey

Datum tie between USGS survey and VTAOT plans

None

Description of reference marks used to determine USGS datum. $\quad$ RM1 is a chiseled X on top of the upstream end of the left abutment (elev. $513.08 \mathrm{ft}$, arbitrary survey datum). RM2 is a chiseled X on top of the downstream end of the right abutment (elev. $513.34 \mathrm{ft}$, arbitrary survey datum).

\section{Cross-Sections Used in WSPRO Analysis}

\begin{tabular}{cccl}
\hline${ }^{1}$ Cross-section & $\begin{array}{c}\text { Section } \\
\text { Reference } \\
\text { Distance } \\
(\text { SRD) } \text { in feet }\end{array}$ & $\begin{array}{c}{ }^{2} \text { Cross-section } \\
\text { development }\end{array}$ & \multicolumn{1}{c}{ Comments } \\
\hline EXIT1 & -144 & 1 & $\begin{array}{l}\text { Downstream section at } \\
\text { island. }\end{array}$ \\
\hline EXITX & -32 & 1 & Exit section \\
FULLV & 0 & 2 & $\begin{array}{l}\text { Downstream Full-valley } \\
\text { section (Templated from } \\
\text { ERIDG }\end{array}$ \\
RDWAY & 0 & 1 & $\begin{array}{l}\text { BXIT) } \\
\text { Bridge section } \\
\text { APPRO }\end{array}$ \\
\hline
\end{tabular}

${ }^{1}$ For location of cross-sections see plan-view sketch included with Level I field form, Appendix E. For more detail on how cross-sections were developed see WSPRO input file. 


\section{Data and Assumptions Used in WSPRO Model}

Hydraulic analyses of the reach were done by use of the Federal Highway Administration's WSPRO step-backwater computer program (Shearman and others, 1986, and Shearman, 1990). The analyses reported herein reflect conditions existing at the site at the time of the study. Furthermore, in the development of the model it was necessary to assume no accumulation of debris or ice at the site. Results of the hydraulic model are presented in the Bridge Hydraulic Summary, Appendix B, and figure 7.

Channel roughness factors (Manning's " $n$ ") used in the hydraulic model were estimated using field inspections at each cross section following the general guidelines described by Arcement and Schneider (1989). Final adjustments to the values were made during the modelling of the reach. Channel " $n$ " values for the reach ranged from 0.045 to 0.055 , and overbank " $\mathrm{n}$ " values ranged from 0.040 to 0.090 .

Normal depth at the exit section (EXITX) was assumed as the starting water surface. This depth was computed by use of the slope-conveyance method outlined in the user's manual for WSPRO (Shearman, 1990). The slope used was $0.022 \mathrm{ft} / \mathrm{ft}$ which was estimated from the topographic map (U.S. Geological Survey, 1986).

The surveyed approach section (APPRO) was surveyed one bridge length upstream of the upstream face as recommended by Shearman and others (1986). This location also provides a consistent method for determining scour variables.

For the 100-and 500-year discharges, WSPRO assumes critical depth at the bridge section. Supercritical models were developed for these discharges. After analyzing both the supercritical and subcritical profiles for each discharge, it can be determined that the water surface profile does pass through critical depth within the bridge opening. Thus, the assumptions of critical depth at the bridge are satisfactory solutions. 


\section{Bridge Hydraulics Summary}

\begin{tabular}{llll} 
Average bridge embankment elevation & 514.1 & $f t$ \\
\cline { 3 - 3 } Average low steel elevation & 509.8 & $\boldsymbol{f t}$
\end{tabular}

100-year discharge $\quad 3,230 \quad \mathrm{ft}^{3} / \mathrm{s}$

Water-surface elevation in bridge opening $\quad 502.9 f t$

Road overtopping? ___ N Discharge over road___

Area of flow in bridge opening $\quad 238 \quad \mathrm{ft}^{2}$

Average velocity in bridge opening $13.6 \mathrm{ft} / \mathrm{s}$

Maximum WSPRO tube velocity at bridge $\quad 16.7 \mathrm{ft} / \mathrm{s}$

Water-surface elevation at Approach section with bridge $\quad 506.4$

Water-surface elevation at Approach section without bridge

Amount of backwater caused by bridge

$2.3 \quad i$

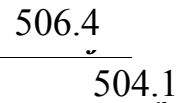

500-year discharge $\quad 4,550 \quad \boldsymbol{f t}^{3} / \mathrm{s}$

Water-surface elevation in bridge opening $504.4 f t$

Road overtopping? ___ N Discharge over road $-f^{3} / s$

Area of flow in bridge opening $\quad 300 \quad \mathrm{ft}^{2}$

Average velocity in bridge opening $15.2 \mathrm{ft} / \mathrm{s}$

Maximum WSPRO tube velocity at bridge 18.8 , 's

Water-surface elevation at Approach section with bridge

Water-surface elevation at Approach section without bridge

Amount of backwater caused by bridge $3.3, t$

508.5

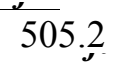

Incipient overtopping discharge ___ -- $\mathrm{ft}^{3} / \mathrm{s}$

Water-surface elevation in bridge opening $\quad--\quad t$

Area of flow in bridge opening $-\boldsymbol{f t}^{2}$

Average velocity in bridge opening $\quad--\quad f t / s$

Maximum WSPRO tube velocity at bridge _-- $f t / s$

Water-surface elevation at Approach section with bridge

Water-surface elevation at Approach section without bridge

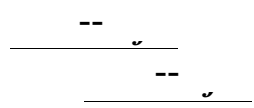
Amount of backwater caused by bridge _ - - it 


\section{Scour Analysis Summary}

\section{Special Conditions or Assumptions Made in Scour Analysis}

Scour depths were computed using the general guidelines described in Hydraulic Engineering Circular 18 (Richardson and others, 1995). Scour depths were calculated assuming an infinite depth of erosive material and a homogeneous particle-size distribution. The results of the scour analysis are presented in tables 1 and 2 and a graph of the scour depths is presented in figure 8 .

Contraction scour was computed by use of the clear-water contraction scour equation (Richardson and others, 1995, p. 32, equation 20). Results of this analysis are presented in figure 8 and tables 1 and 2 . The streambed armoring depths computed suggest that armoring will not limit the depth of contraction scour.

Abutment scour was computed by use of the Froehlich equation (Richardson and others, 1995, p. 48, equation 28). Variables for the Froehlich equation include the Froude number of the flow approaching the embankments, the length of the embankment blocking flow, and the depth of flow approaching the embankment less any roadway overtopping. 


\section{Scour Results}

\section{0-yr discharge 500-yr discharge}

Contraction scour:

(Scour depths in feet)

Main channel

Live-bed scour

Clear-water scour

Depth to armoring

Left overbank

Right overbank

Local scour:

Abutment scour

Left abutment

15.4

18.5

$12.3-$

$15.3-$

Right abutment

Pier scour

Pier 1

Pier 2

Pier 3

\section{Abutments:}

Left abutment

Right abutment

Piers:

Pier 1

Pier 2

\section{Riprap Sizing}

Incipient overtopping 100-yr discharge 500-yrdischarge discharge

2.4

2.4

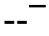

$--$

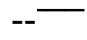
( $D_{50}$ in feet)

3.0

3.0

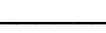

$--$

$-$


overtopping discharge 


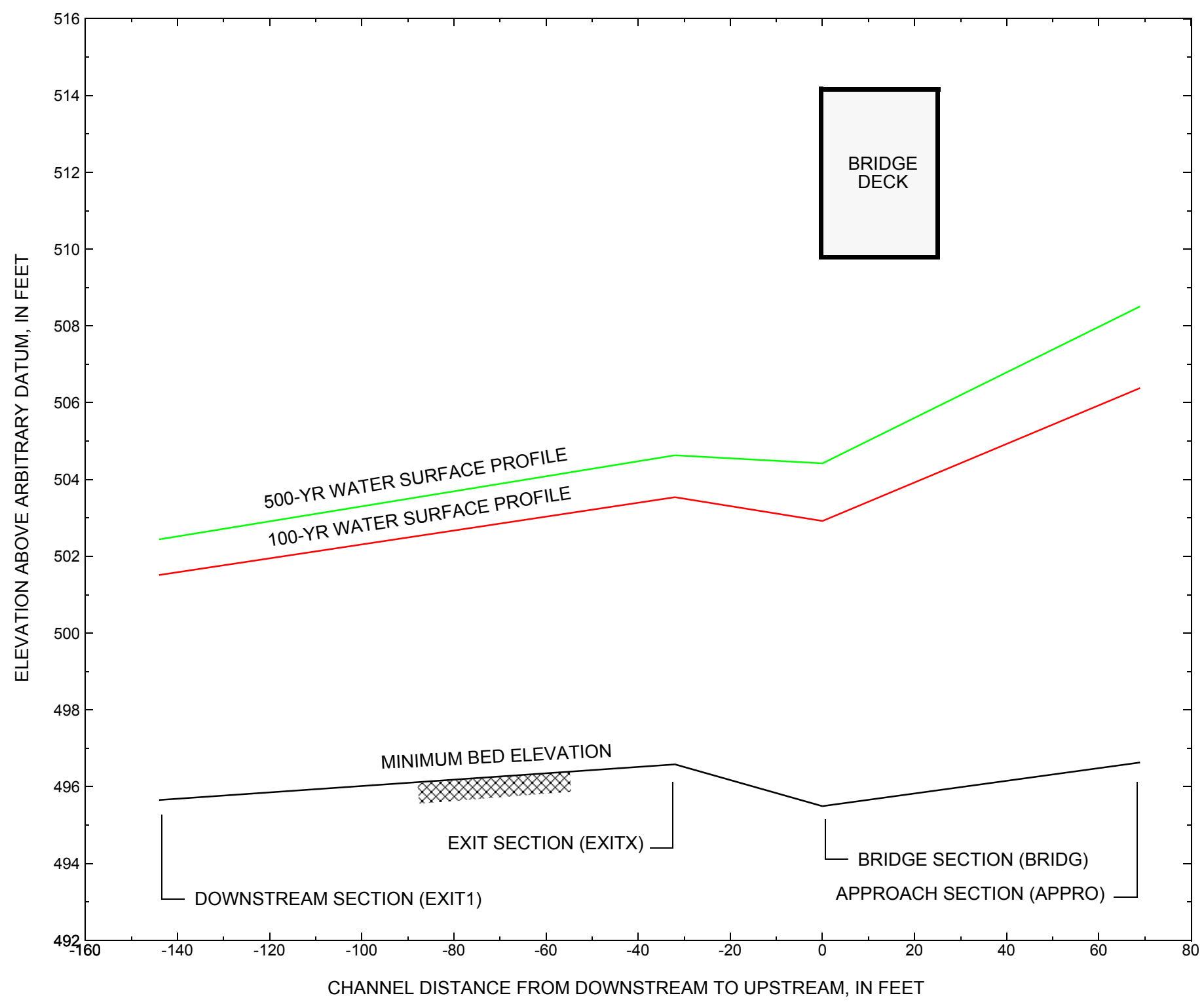

Figure 7. Water-surface profiles for the 100- and 500-yr discharges at structure JAY-TH00040001 on Town Highway 4, crossing Crook Brook, Jay, Vermont. 




Figure 8. Scour elevations for the 100-yr and 500-yr discharges at structure JAY-TH00040001 on Town Highway 4, crossing Crook Brook, Jay, Vermont. 
Table 1. Remaining footing/pile depth at abutments for the 100-year discharge at structure JAY-TH00040001 on Town Highway 4, crossing Crook Brook, Jay, Vermont. [VTAOT, Vermont Agency of Transportation; --,no data]

\begin{tabular}{|c|c|c|c|c|c|c|c|c|c|c|c|}
\hline Description & Station $^{1}$ & $\begin{array}{l}\text { VTAOT } \\
\text { minimum } \\
\text { low-chord } \\
\text { elevation } \\
\text { (feet) }\end{array}$ & $\begin{array}{c}\text { Surveyed } \\
\text { minimum } \\
\text { low-chord } \\
\text { elevation } \\
\text { (feet) }\end{array}$ & $\begin{array}{c}\text { Bottom of } \\
\text { footing } \\
\text { elevation } \\
\text { (feet) }\end{array}$ & $\begin{array}{c}\text { Channel } \\
\text { elevation at } \\
\text { abutment/ } \\
\text { pier }^{2} \\
\text { (feet) }\end{array}$ & $\begin{array}{l}\text { Contraction } \\
\text { scour depth } \\
\text { (feet) }\end{array}$ & $\begin{array}{l}\text { Abutment } \\
\text { scour } \\
\text { depth } \\
\text { (feet) }\end{array}$ & $\begin{array}{l}\text { Pier } \\
\text { scour } \\
\text { depth } \\
\text { (feet) }\end{array}$ & $\begin{array}{l}\text { Depth of } \\
\text { total scour } \\
\text { (feet) }\end{array}$ & $\begin{array}{c}\text { Elevation of } \\
\text { scour }^{2} \\
\text { (feet) }\end{array}$ & $\begin{array}{c}\text { Remaining } \\
\text { footing/pile } \\
\text { depth } \\
\text { (feet) }\end{array}$ \\
\hline \multicolumn{12}{|c|}{100 -yr. discharge is 3,230 cubic-feet per second } \\
\hline Left abutment & 0.0 & -- & 509.8 & -- & 498.2 & 2.5 & 15.4 & -- & 17.9 & 480.3 & -- \\
\hline Right abutment & 42.0 & -- & 509.8 & -- & 497.7 & 2.5 & 12.3 & -- & 14.8 & 482.9 & -- \\
\hline
\end{tabular}

1.Measured along the face of the most constricting side of the bridge.

2.Arbitrary datum for this study.

Table 2. Remaining footing/pile depth at abutments for the 500-year discharge at structure JAY-TH00040001 on Town Highway 4, crossing Crook Brook, Jay, Vermont. [VTAOT, Vermont Agency of Transportation; --, no data]

\begin{tabular}{|c|c|c|c|c|c|c|c|c|c|c|c|}
\hline Description & Station $^{1}$ & $\begin{array}{l}\text { VTAOT } \\
\text { minimum } \\
\text { low-chord } \\
\text { elevation } \\
\text { (feet) }\end{array}$ & $\begin{array}{l}\text { Surveyed } \\
\text { minimum } \\
\text { low-chord } \\
\text { elevation }{ }^{2} \\
\text { (feet) }\end{array}$ & $\begin{array}{l}\text { Bottom of } \\
\text { footing } \\
\text { elevation } \\
\text { (feet) }\end{array}$ & $\begin{array}{c}\text { Channel } \\
\text { elevation at } \\
\text { abutment/ } \\
\text { pier }^{2} \\
\text { (feet) }\end{array}$ & $\begin{array}{l}\text { Contraction } \\
\text { scour depth } \\
\text { (feet) }\end{array}$ & $\begin{array}{l}\text { Abutment } \\
\text { scour } \\
\text { depth } \\
\text { (feet) }\end{array}$ & $\begin{array}{l}\text { Pier } \\
\text { scour } \\
\text { depth } \\
\text { (feet) }\end{array}$ & $\begin{array}{l}\text { Depth of } \\
\text { total scour } \\
\text { (feet) }\end{array}$ & $\begin{array}{c}\text { Elevation of } \\
\text { scour }^{2} \\
\text { (feet) }\end{array}$ & $\begin{array}{c}\text { Remaining } \\
\text { footing/pile } \\
\text { depth } \\
\text { (feet) }\end{array}$ \\
\hline \multicolumn{12}{|c|}{500 -yr. discharge is 4,550 cubic-feet per second } \\
\hline Left abutment & 0.0 & -- & 509.8 & -- & 498.2 & 3.8 & 18.5 & -- & 22.3 & 475.9 & -- \\
\hline Right abutment & 42.0 & -- & 509.8 & -- & 497.7 & 3.8 & 15.3 & -- & 19.1 & 478.6 & -- \\
\hline
\end{tabular}

1.Measured along the face of the most constricting side of the bridge.

2.Arbitrary datum for this study. 


\section{SELECTED REFERENCES}

Arcement, G.J., Jr., and Schneider, V.R., 1989, Guide for selecting Manning's roughness coefficients for natural channels and flood plains: U.S. Geological Survey Water-Supply Paper 2339, 38 p.

Barnes, H.H., Jr., 1967, Roughness characteristics of natural channels: U.S. Geological Survey Water-Supply Paper 1849,213 p.

Benson, M. A., 1962, Factors Influencing the Occurrence of Floods in a Humid Region of Diverse Terrain: U.S. Geological Survey WaterSupply Paper 1580-B, 64 p.

Brown, S.A. and Clyde, E.S., 1989, Design of riprap revetment: Federal Highway Administration Hydraulic Engineering Circular No. 11, Publication FHWA-IP-89-016, 156 p.

Federal Highway Administration, 1983, Runoff estimates for small watersheds and development of sound design: Federal Highway Administration Report FHWA-RD-77-158.

Federal Highway Administration, 1993, Stream Stability and Scour at Highway Bridges: Participant Workbook: Federal Highway Administration Report FHWA-HI-91-011.

Froehlich, D.C., 1989, Local scour at bridge abutments in Ports, M.A., ed., Hydraulic Engineering--Proceedings of the 1989 National Conference on Hydraulic Engineering: New York, American Society of Civil Engineers, p. 13-18.

Hayes, D.C.,1993, Site selection and collection of bridge-scour data in Delaware, Maryland, and Virginia: U.S. Geological Survey WaterResources Investigation Report 93-4017, 23 p.

Interagency Advisory Committee on Water Data, 1982, Guidelines for determining flood flow frequency: U.S. Geological Survey, Bulletin 17B of the Hydrology Subcommittee, 190 p.

Johnson, C.G. and Tasker, G.D.,1974, Progress report on flood magnitude and frequency of Vermont streams: U.S. Geological Survey OpenFile Report 74-130, 37 p.

Lagasse, P.F., Schall, J.D., Johnson, F., Richardson, E.V., Chang, F., 1995, Stream Stability at Highway Structures: Federal Highway Administration Hydraulic Engineering Circular No. 20, Publication FHWA-IP-90-014, 144 p.

Laursen, E.M., 1960, Scour at bridge crossings: Journal of the Hydraulics Division, American Society of Civil Engineers, v. 86, no. HY2, p. 39-53.

Potter, W. D., 1957a, Peak rates of runoff in the Adirondack, White Mountains, and Maine woods area, Bureau of Public Roads

Potter, W. D., 1957b, Peak rates of runoff in the New England Hill and Lowland area, Bureau of Public Roads

Richardson, E.V. and Davis, S.R., 1995, Evaluating scour at bridges: Federal Highway Administration Hydraulic Engineering Circular No. 18, Publication FHWA-IP-90-017, 204 p.

Richardson, E.V., Simons, D.B., and Julien, P.Y., 1990, Highways in the river environment: Federal Highway Administration Publication FHWA-HI-90-016.

Ritter, D.F., 1984, Process Geomorphology: W.C. Brown Co., Debuque, Iowa, 603 p.

Shearman, J.O., 1990, User's manual for WSPRO--a computer model for water surface profile computations: Federal Highway Administration Publication FHWA-IP-89-027, 187 p.

Shearman, J.O., Kirby, W.H., Schneider, V.R., and Flippo, H.N., 1986, Bridge waterways analysis model; research report: Federal Highway Administration Publication FHWA-RD-86-108, 112 p.

Talbot, A.N., 1887, The determination of water-way for bridges and culverts.

U.S. Department of Transportation, 1993, Stream stability and scour at highway bridges, Participant Workbook: Federal Highway Administration Publication FHWA HI-91-011.

U.S. Geological Survey, 1986, North Troy, Vermont 7.5 Minute Series quadrangle map: U.S. Geological Survey Topographic Maps, Scale $1: 24,000$. 


\section{APPENDIX A: \\ WSPRO INPUT FILE}




\section{WSPRO INPUT FILE}

GR

GR

GR

GR

$\mathrm{N}$

SA

*

XS

GR

GR

GR

GR

GR

$\mathrm{N}$

SA

*

XS

BR

GR

GR

GR

GR

$\mathrm{N}$

CD

GR

GR

GR

*

AS

GR

GR

GR

GR

$\mathrm{N}$

SA

*

HP 1 BRIDG

HP 2 BRIDG

HP 1 APPRO

HP 2 APPRO

*

HP 1 BRIDG

HP 2 BRIDG

HP 1 APPRO

BRIDG

RDWAY
U.S. Geological Survey WSPRO Input File jay-001.wsp Hydraulic analysis for structure jay-th00040001 Date: 09-APR-97 Jay bridge 1 over Crook Brook.

$\begin{array}{lllllllllllllllllllll}6 & 29 & 30 & 552 & 553 & 551 & 5 & 16 & 17 & 13 & 3 & * & 15 & 14 & 23 & 21 & 11 & 12 & 4 & 7 & 3\end{array}$

$3230 \quad 4550$

$0.022 \quad 0.022$

EXIT1 - 144

$-74.2,507.53$

$0.0,496.13$

$-20.8,500.11$

$-18.0,497.33$

$-11.0,495.79$

$7.5,497.35$

$12.1,498.89$

$29.8,500.33$

$43.9,499.34$

$48.0,496.89$

$56.1,495.65$

$62.1,495.90$

$62.2,496.43$

$65.3,496.86$

0.085

0.055

0.090

$73.2,500.04$

$102.5,518.88$

43.9

0.055

$$
-20.8
$$

12.1

EXITX -32

$-55.6,515.51$

$-40.6, \quad 506.69$

$-19.9,502.96$

$-18.0,499.88$

$0.0,497.16$

$32.3,497.64$

$17.3,496.60$

$25.8,496.70$

$62.8,502.30$

$10.4,496.61$

$39.5,496.58$

$87.0,508.62$

$108.5,518.43$

0.090

0.045

$-19.9$

FULLV 0

$0 \quad 509.75 \quad 5$

$0.0,509.75$

$1.0,499.79$

$3.3,499.77$

$3.5,498.55$

$4.4,498.24$

$5.9,497.53$

$10.2,496.24$

$14.9,495.49$

$25.6,497.10$

$32.3,497.67$

$41.9,497.73$

$42.0,498.19$

$42.7,509.75$

$0.0,509.75$

0.045

$132 * \star 27.512 .7$

$\begin{array}{lll}12 & 212\end{array}$

$-80.8,519.94$

$-45.8,517.28$

$-23.5,514.98$

$-11.1,513.98$

$0.0,514.07$

$20.2,514.21$

$22.0,514.23$

$43.1,514.19$

$61.8,513.94$

$93.6,515.14$

$125.9,516.74$

$189.6,519.90$

$-45.3, \quad 517.13$
$2.1, \quad 497.55$
$34.2, \quad 498.30$
$82.0, \quad 507.62$
0.055

$-24.6,503.28$

$-8.6,499.85$

$10.8,497.20$

$16.4,497.07$

$0.0,498.17$

$42.0,498.83$

$55.6,502.55$

$24.4,496.63$

$64.3,505.71$

$98.5,509.82$

$128.4,511.93$

$171.5,519.10$

\section{3}

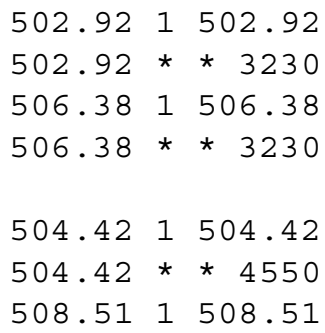




\section{APPENDIX B: \\ WSPRO OUTPUT FILE}


WSPRO OUTPUT FILE

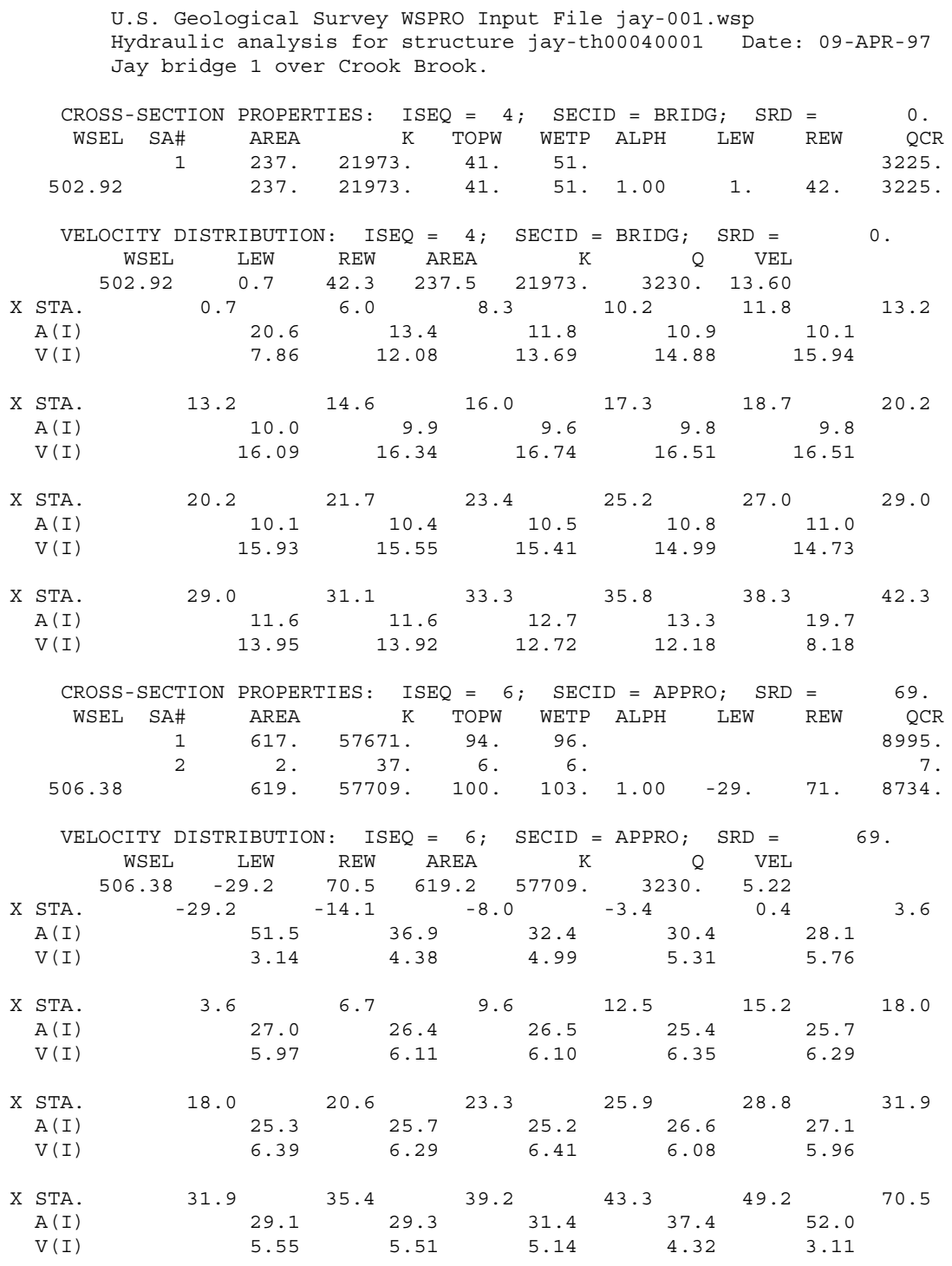


WSPRO OUTPUT FILE (continued)

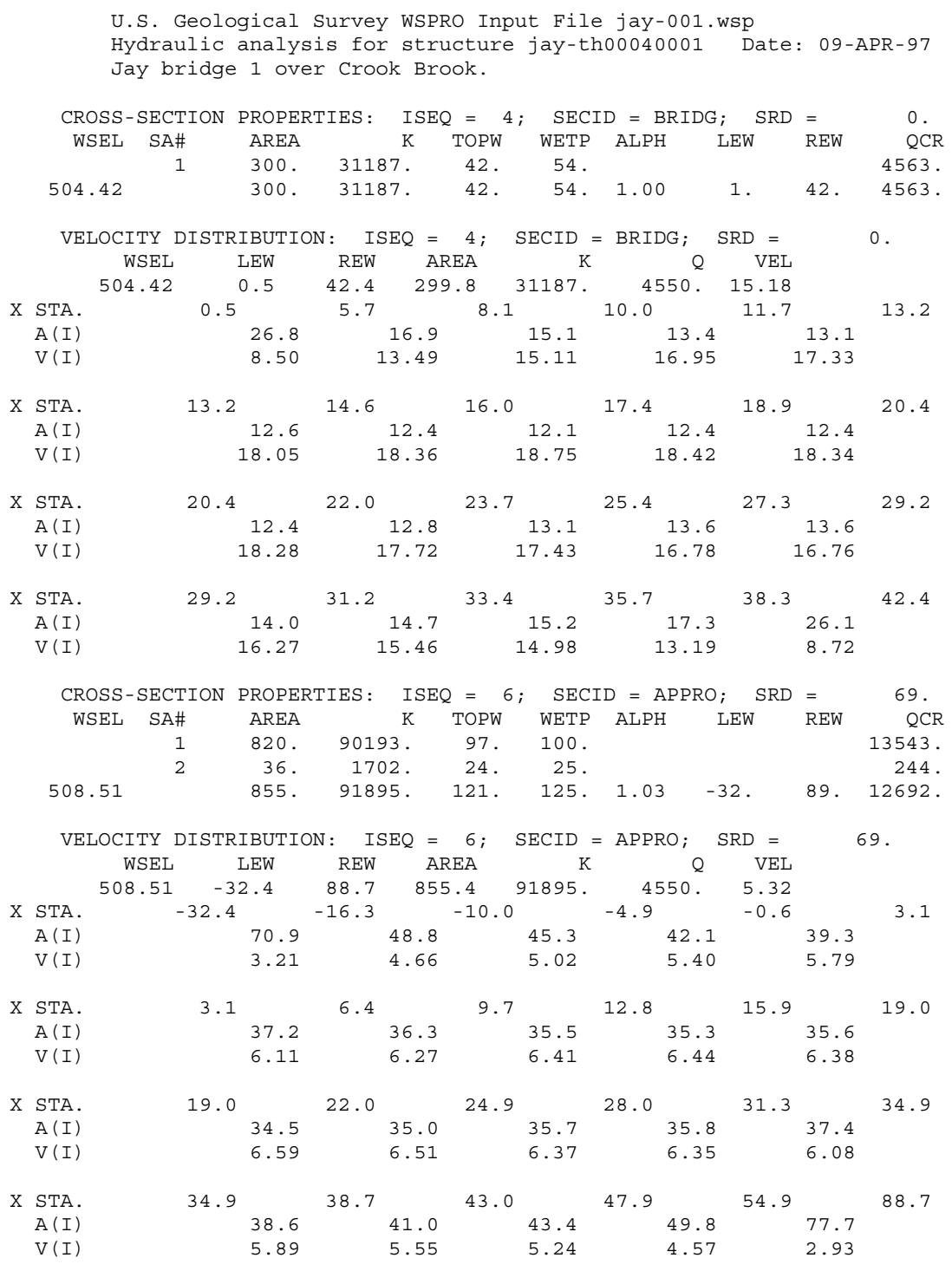


WSPRO OUTPUT FILE (continued)

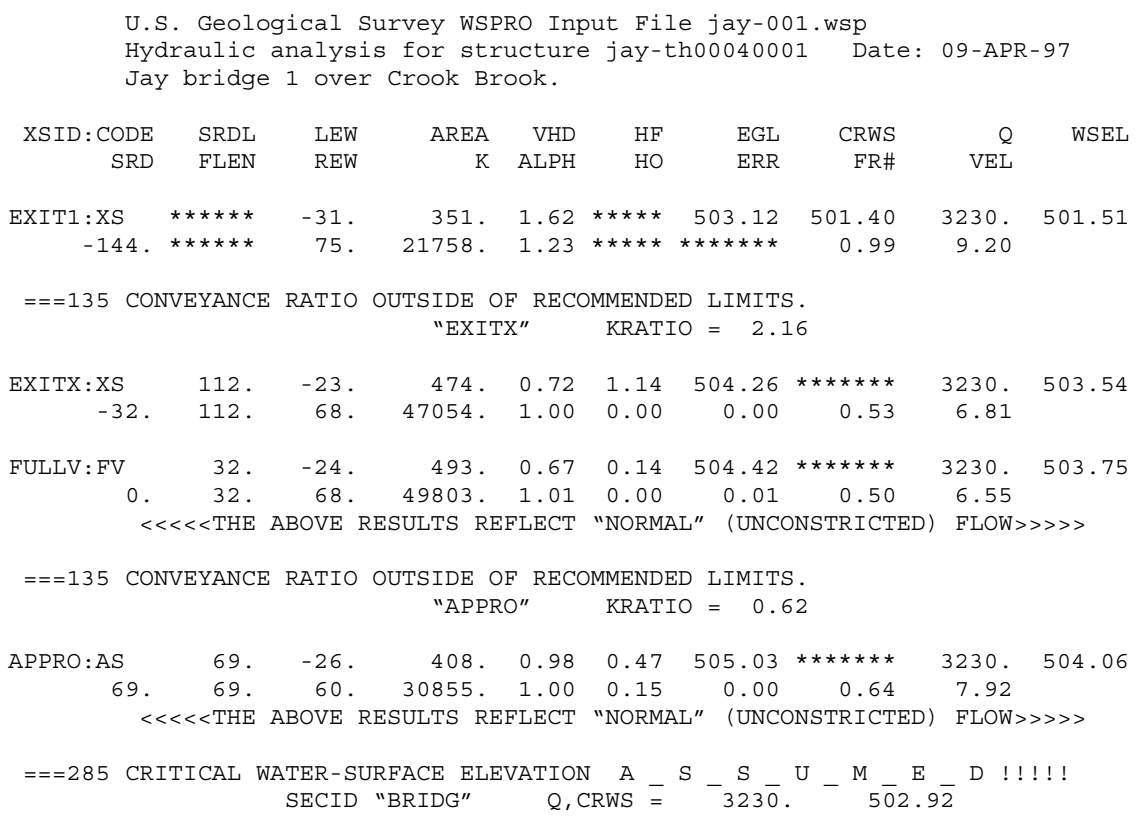

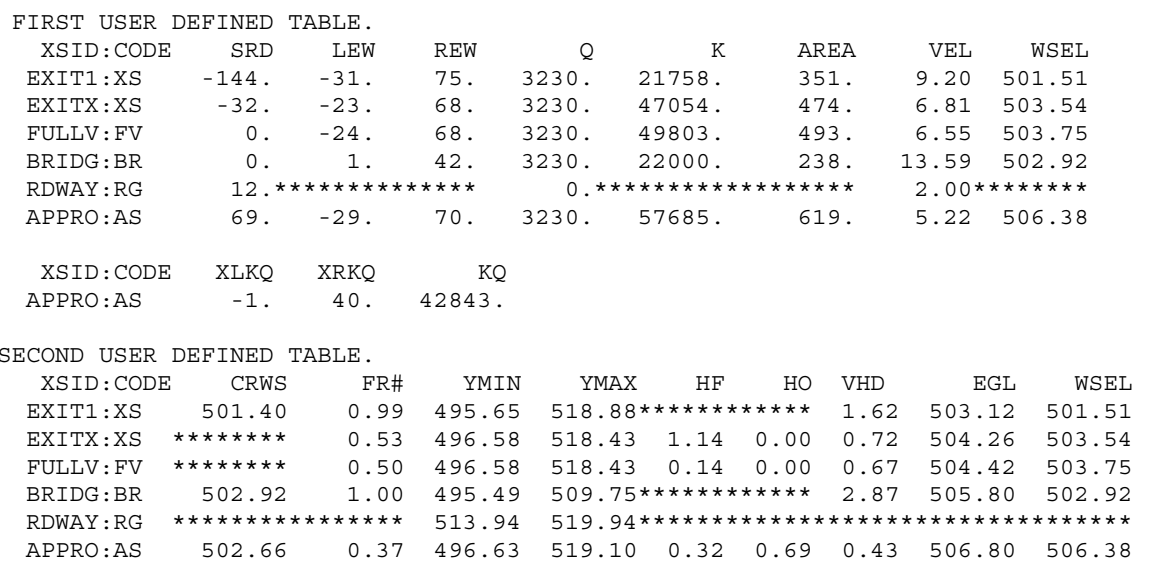


WSPRO OUTPUT FILE (continued)

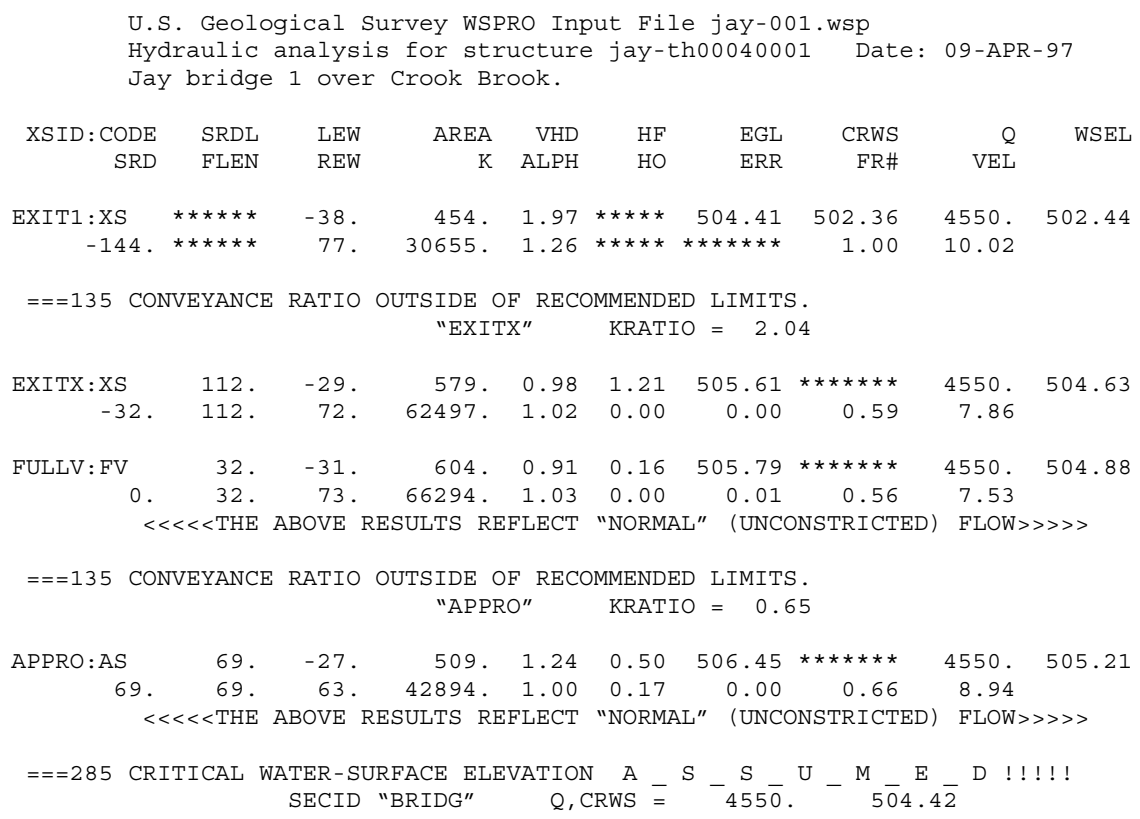

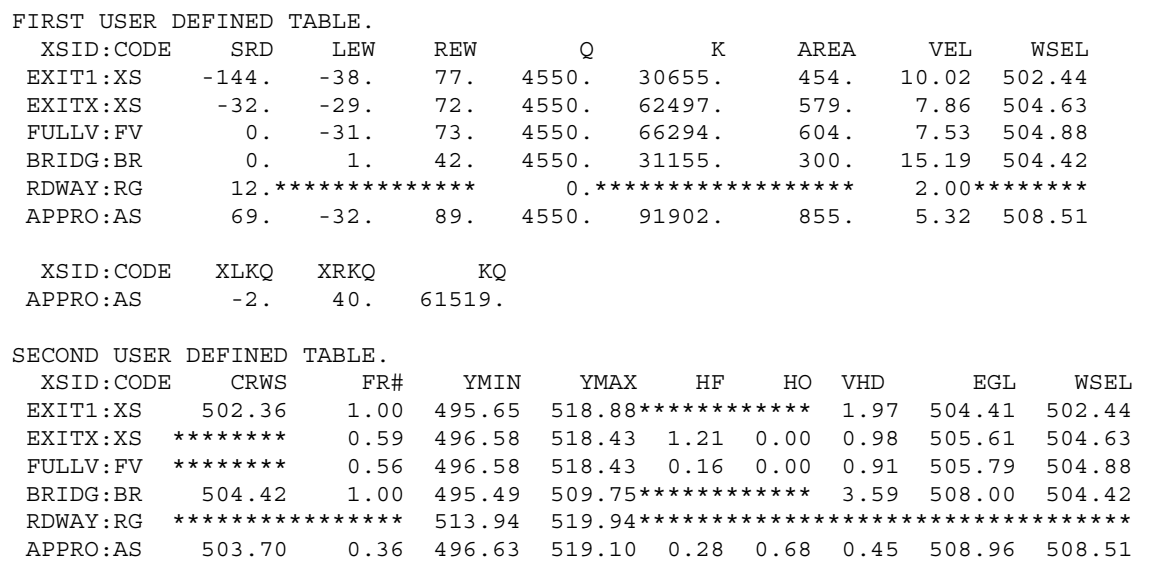




\section{APPENDIX C:}

\section{BED-MATERIAL PARTICLE-SIZE DISTRIBUTION}




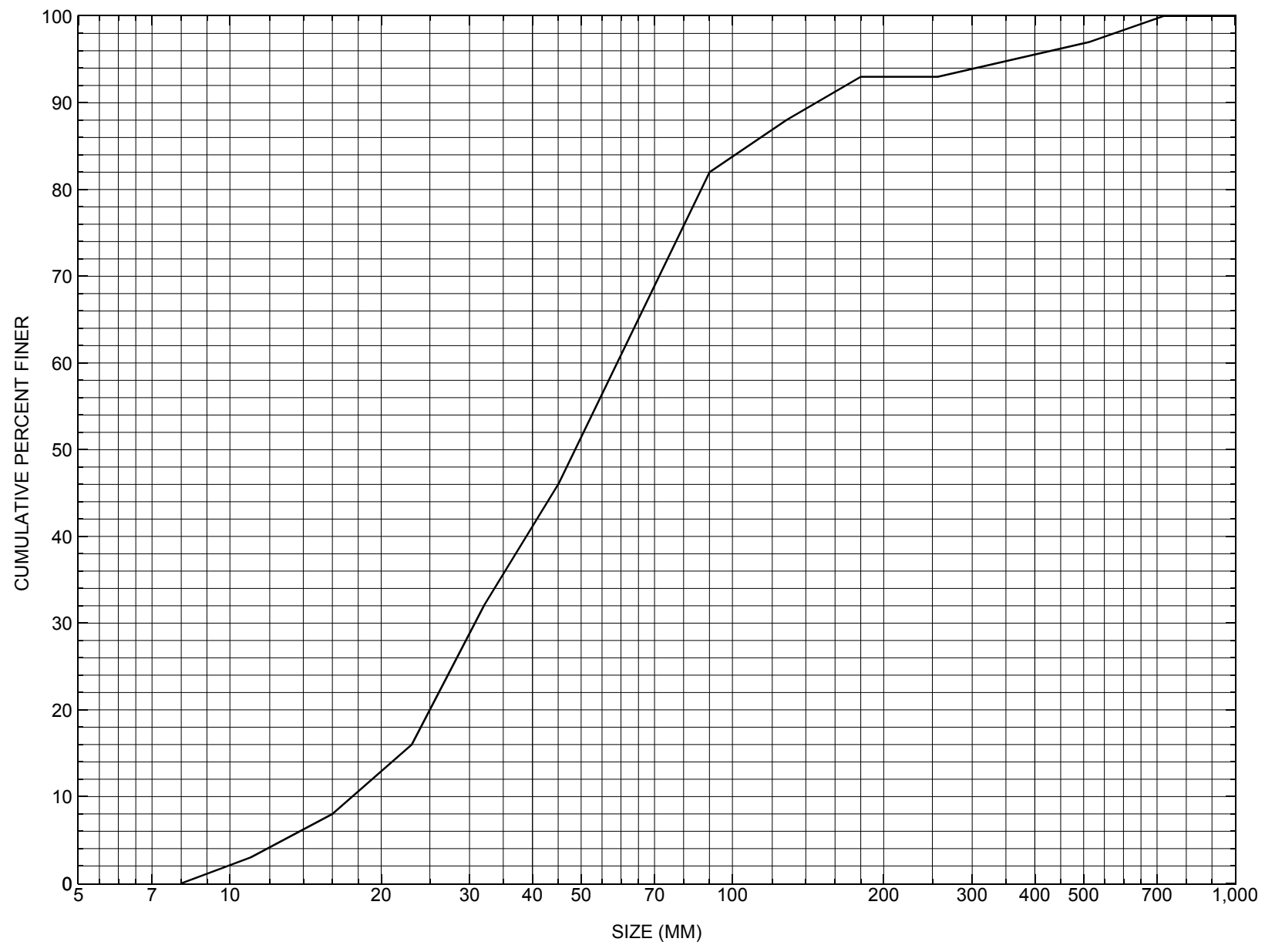

Appendix C. Bed material particle-size distribution for a pebble count in the channel approach of structure JAY-TH00040001, in Jay, Vermont. 


\section{APPENDIX D: \\ HISTORICAL DATA FORM}




\section{Structure Number JAY-TH00040001}

\section{General Location Descriptive}

Data collected by (First Initial, Full last name) $\underline{\text { L }}$. MEDALIE

Date $(M M / D D / Y Y) \quad \mathbf{0 3} / \underline{06} / \underline{95}$

Highway District Number (I - 2; nn) $\mathbf{0 9}$

County (FIPS county code; I - 3; nnn)

Town (FIPS place code; I - 4; nnnnn) $\mathbf{3 6 3 2 5}$

Mile marker (I - 11; nnn.nnn) $\underline{\mathbf{0 0 0 0 0 0}}$

Waterway (I - 6) CROOK BROOK

Road Name (I - 7): -

Route Number TH004

Vicinity (I - 9) 0.18 MI TO JCT W VT105

Topographic Map North Troy

Hydrologic Unit Code: $\underline{\mathbf{0 2 0 1 0 0 0 7}}$

Latitude (I - 16; nnnn.n) $\mathbf{4 4 5 7 8}$

Longitude (i - 17; nnnnn.n) $\mathbf{7 2 2 6 0}$

\section{Select Federal Inventory Codes}

FHWA Structure Number (I - 8) 10101200011012

Maintenance responsibility $(I-21 ; n n) \quad \mathbf{0 3} \quad$ Maximum span length $(I-48 ; n n n n) \underline{\mathbf{0 0 4 5}}$

Year built (I - 27; YYYY) 1931

Structure length (I - 49; nnnnnn) $\underline{000049}$

Average daily traffic, ADT (I - 29; nnnnnn) $\underline{000070}$

Deck Width (I - 52; nn.n) 213

Year of ADT (I - 30; YY) $\mathbf{9 1}$

Channel \& Protection $(I-61 ; n) \underline{\mathbf{6}}$

Opening skew to Roadway $(I-34 ; n n) \quad \mathbf{0 0}$

Waterway adequacy $(I-71 ; n) \underline{6}$

Operational status $(I-41 ; X)$ A

Underwater Inspection Frequency $(I-92 B ; X Y Y) \_\mathbf{N}$

Structure type (I - 43; nnn) 104

Year Reconstructed (I - 106) $\mathbf{0 0 0 0}$

Approach span structure type (I - 44; nnn) $\mathbf{0 0 0}$

Clear span (nnn.n ft) $\mathbf{4 2}$

Number of spans (I - 45; nnn) $\underline{\mathbf{0 0 1}}$

Vertical clearance from streambed (nnn.n ft) $\underline{\mathbf{1 2 . 0}}$

Number of approach spans (I - 46; nnnn) $\mathbf{0 0 0 0}$

Waterway of full opening (nnn.n $\left.\mathrm{ft}^{2}\right) \mathbf{5 0 4}$

Comments:

The structural inspection report of 5/27/93 indicates the structure is a single span concrete T-beam type bridge. The footing is not exposed along right abutment, but is exposed along left abutment. There is a newer concrete subfooting directly in front of the left abutment. There are some random boulders in front of the subfooting. The waterway makes a moderate turn just upstream, and has a relatively straight alignment through the structure. There is a large boulder and gravel bar in the middle of the channel, roughly 150 feet downstream. The streambed consists of boulders and gravel. There are some medium sized boulders along with some random larger boulders. 


\section{Bridge Hydrologic Data}

Is there hydrologic data available? $\underline{\mathbf{N}}$ if No, type ctrl-n $h \quad$ VTAOT Drainage area $\left(m i^{2}\right)$ : -

Terrain character:

Stream character \& type: -

Streambed material:

Discharge Data (cfs):

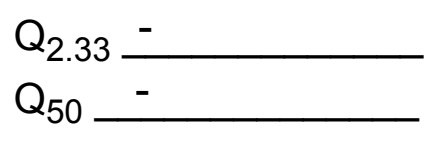

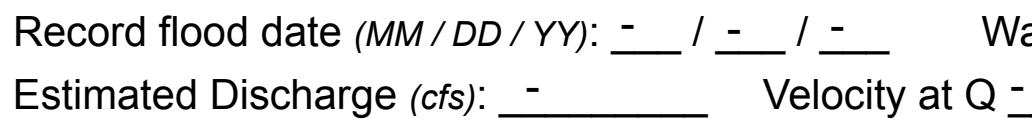

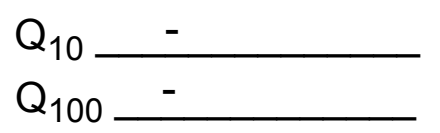

$\mathrm{Q}_{25}$

Water surface elevation $(f t):-$ $(\mathrm{ft} / \mathrm{s}):$

Ice conditions (Heavy, Moderate, Light) : -

Debris (Heavy, Moderate, Light):

The stage increases to maximum highwater elevation (Rapidly, Not rapidly):

The stream response is (Flashy, Not flashy):

Describe any significant site conditions upstream or downstream that may influence the stream's stage:

Watershed storage area (in percent):

The watershed storage area is: - (1-mainly at the headwaters; 2- uniformly distributed; 3-immediatly upstream oi the site)

Water Surface Elevation Estimates for Existing Structure:

\begin{tabular}{|l|l|l|l|l|l|}
\hline Peak discharge frequency & $Q_{2.33}$ & $Q_{10}$ & $Q_{25}$ & $Q_{50}$ & $Q_{100}$ \\
Water surface elevation (ft)) & - & - & - & - & - \\
Velocity (ft/sec) & - & - & - & - & - \\
\hline
\end{tabular}

Long term stream bed changes: -

Is the roadway overtopped below the $Q_{100}$ ? (Yes, No, Unknown):

Frequency: -

Relief Elevation (ft):

Discharge over roadway at $Q_{100}\left(f^{3} / \mathrm{sec}\right)$ :

Are there other structures nearby? (Yes, No, Unknown): Upstream distance (miles): Town: If No or Unknown, type ctrl-n os Highway No. : Structure No. : Year Built:

Clear span (ft): Clear Height (ft): Full Waterway $\left(f^{2}\right)$ : 
Downstream distance (miles): Town: Year Built:

Highway No. : Structure No. : Structure Type:

Clear span (ft): Clear Height $(f t)$ : Full Waterway $\left(f t^{2}\right)$ :

Comments:

Inspection report states that there is minor streambank erosion with little stone fill present. The report indicates settling is not evident.

\section{USGS Watershed Data}

Watershed Hydrographic Data

Drainage area $(D A) \stackrel{\mathbf{2 0 . 7 4}}{\mathrm{mi}^{2}}$ Lake and pond area $\mathbf{0 . 0 5}$ $\mathrm{mi}^{2}$

Watershed storage (ST) 0.2

Bridge site elevation 866 $\mathrm{ft}$ $\%$

Main channel length $\mathbf{7 . 1 1}$ mi $10 \%$ channel length elevation $\mathbf{9 6 5}$ $\mathrm{ft} \quad 85 \%$ channel length elevation 2038 $\mathrm{ft}$

Main channel slope $(S)$
(S) 202.47 $\mathrm{ft} / \mathrm{mi}$

Watershed Precipitation Data

Average site precipitation in Average headwater precipitation in

Maximum 2yr-24hr precipitation event $(124,2)$ in

Average seasonal snowfall (Sn) $\mathrm{ft}$ 


\section{Bridge Plan Data}

Are plans available? If no, type ctrl-n pl

Project Number --

Minimum channel bed elevation: --

Low superstructure elevation: USLAB -DSLAB --

Benchmark location description:

NO BENCHMARK INFORMATION

Reference Point (MSL, Arbitrary, Other):

Datum (NAD27, NAD83, Other):

Foundation Type: 4

If 1: Footing Thickness

If 2: Pile Type: (1-Wood; 2-Steel or metal; 3-Concrete)

(1-Spreadfooting; 2-Pile; 3- Gravity; 4-Unknown) USRAB -DSRAB --

If 3: Footing bottom elevation:

Is boring information available? $\mathbf{N}$ If no, type ctrl-n bi Number of borings taken:

Foundation Material Type: $\mathbf{3}$ (1-regolith, 2-bedrock, 3-unknown)

Briefly describe material at foundation bottom elevation or around piles:

NO FOUNDATION MATERIAL INFORMATION

Comments:

NO PLANS. 


\section{Cross-sectional Data}

Is cross-sectional data available? $\mathbf{N}$ If no, type ctrl-n xs

Source (FEMA, VTAOT, Other)? -

Comments:

\section{NO CROSS SECTION INFORMATION}

\begin{tabular}{|l|l|l|l|l|l|l|l|l|l|l|l|}
\hline Station & - & - & - & - & - & - & - & - & - & - & - \\
\hline Feature & - & - & - & - & - & - & - & - & - & - & - \\
\hline $\begin{array}{l}\text { Low cord } \\
\text { elevation }\end{array}$ & - & - & - & - & - & - & - & - & - & - & - \\
\hline $\begin{array}{l}\text { Bed } \\
\text { elevation }\end{array}$ & - & - & - & - & - & - & - & - & - & - & - \\
\hline $\begin{array}{l}\text { Low cord to } \\
\text { bed length }\end{array}$ & - & - & - & - & - & - & - & - & - & - & - \\
\hline Station & - & - & - & - & - & - & - & - & - & - & - \\
\hline Feature & - & - & - & - & - & - & - & - & - & - & - \\
\hline $\begin{array}{l}\text { Low cord } \\
\text { elevation }\end{array}$ & - & - & - & - & - & - & - & - & - & - & - \\
\hline $\begin{array}{l}\text { Bed } \\
\text { elevation }\end{array}$ & - & - & - & - & - & - & - & - & - & - & - \\
\hline $\begin{array}{l}\text { Low cord to } \\
\text { bed length }\end{array}$ & - & - & - & - & - & - & - & - & - & - & - \\
\hline
\end{tabular}

Source (FEMA, VTAOT, Other)? NO

Comments: CROSS SECTION INFORMATION

\begin{tabular}{|l|l|l|l|l|l|l|l|l|l|l|l|}
\hline Station & - & - & - & - & - & - & - & - & - & - & - \\
\hline Feature & - & - & - & - & - & - & - & - & - & - & - \\
\hline $\begin{array}{l}\text { Low cord } \\
\text { elevation }\end{array}$ & - & - & - & - & - & - & - & - & - & - & - \\
\hline $\begin{array}{l}\text { Bed } \\
\text { elevation }\end{array}$ & - & - & - & - & - & - & - & - & - & - & - \\
\hline $\begin{array}{l}\text { Low cord to } \\
\text { bed length }\end{array}$ & - & - & - & - & - & - & - & - & - & - & - \\
\hline Station & - & - & - & - & - & - & - & - & - & - & - \\
\hline Feature & - & - & - & - & - & - & - & - & - & - & - \\
\hline $\begin{array}{l}\text { Low cord } \\
\text { elevation }\end{array}$ & - & - & - & - & - & - & - & - & - & - & - \\
\hline $\begin{array}{l}\text { Bed } \\
\text { levation }\end{array}$ & - & - & - & - & - & - & - & - & - & - & - \\
\hline $\begin{array}{l}\text { Low cord to } \\
\text { bed length }\end{array}$ & - & - & - & - & - & - & - & - & - & - & - \\
\hline
\end{tabular}




\section{APPENDIX E: \\ LEVEL I DATA FORM}


U. S. Geological Survey

Bridge Field Data Collection and Processing Form

Qa/Qc Check by: EW Date: $\underline{\mathbf{0 4} / 04 / 96}$

\section{Structure Number JAY-TH00040001} Computerized by: EW Date: 04/05/96

Reviewd by: SAO Date: $\underline{\mathbf{5} / \mathbf{5} / \mathbf{9 7}}$

\section{A. General Location Descriptive}

1. Data collected by (First Initial, Full last name) D. SONG

2. Highway District Number 09

Date $(M M / D D / Y Y) 06$ / 05 / 1995

County ORLEANS (019)

Waterway (I - 6) CROOK BROOK

Route Number TH4

Mile marker -

Town JAY (36325)

Road Name REVOIR FLATS ROAD

Hydrologic Unit Code: $\mathbf{0 2 0 1 0 0 0 7}$

3. Descriptive comments:

LOCATED 0.18 MILES TO JUNCTION WITH VT105. SLIGHT BEND IN WATERWAY UPSTREAM.

CONCRETE T-BEAM BRIDGE.

\section{B. Bridge Deck Observations}
4. Surface cover... LBUS 5
RBUS 4
LBDS 6
RBDS 6
Overall 6

(2b us,ds,lb,rb: 1- Urban; 2- Suburban; 3- Row crops; 4- Pasture; 5- Shrub- and brushland; 6- Forest; 7- Wetland)
5. Ambient water surface...US 2
UB 1 DS 2
(1- pool; 2- riffle)

6. Bridge structure type 1 (1- single span; 2- multiple span; 3- single arch; 4- multiple arch; 5-cylindrical culvert; 6- box culvert; or 7- other)
7. Bridge length 49
(feet)
Span length 45
(feet)
Bridge width 21.3 (feet)

\section{Road approach to bridge:}
8. LB RB 2
( 0 even, 1- lower, 2- higher)
9. LB_ RB $\underline{2}$ (1- Paved, 2- Not paved)

10. Embankment slope (run / rise in feet / foot):

$$
\text { US left }
$$

2.1:1

US right

1.5:1

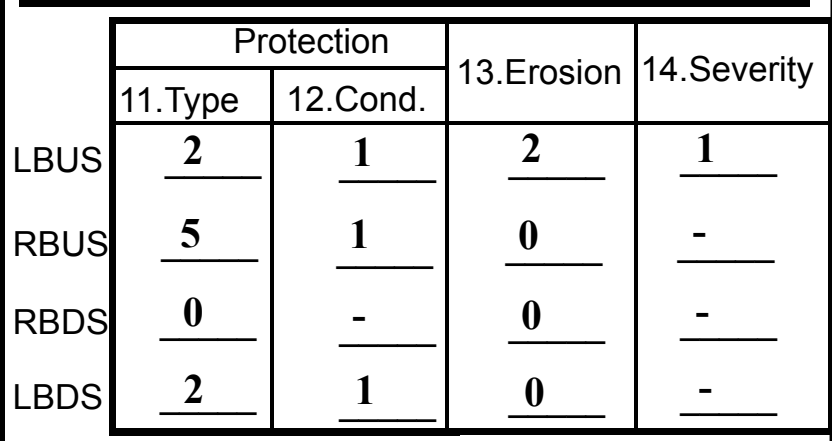

Bank protection types: 0- none; 1- $<12$ inches; 2- < 36 inches; 3- < 48 inches;

4- < 60 inches; 5- wall / artificial levee

Bank protection conditions: 1- good; 2- slumped;

3- eroded; 4- failed

Erosion: 0 - none; 1- channel erosion; 2 -

road wash; 3- both; 4- other

Erosion Severity: 0 - none; 1- slight; 2- moderate; 3- severe

\section{Channel approach to bridge (BF):}

15. Angle of approach: 5

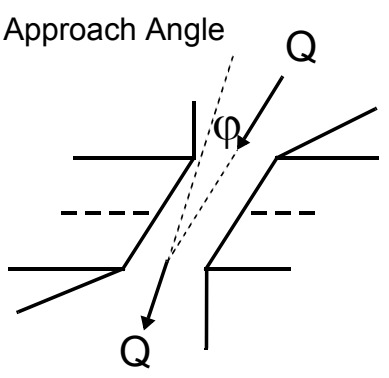

17. Channel impact zone 1:

Where? LB (LB, RB)

Range? 15 feet US

Channel impact zone 2:

Where? (LB, RB)

Range? feet (US, UB, DS) to feet

16. Bridge skew: $\mathbf{5}$ Bridge Skew Angle

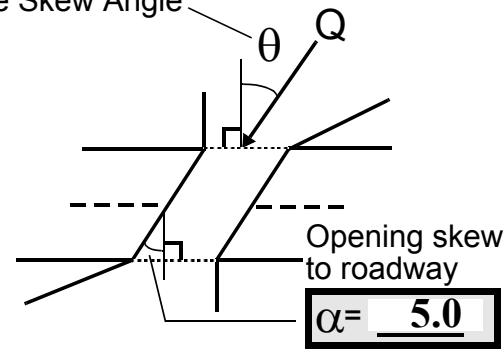

\section{Exist? $\mathbf{Y}(Y$ or $N)$}

Severity 1

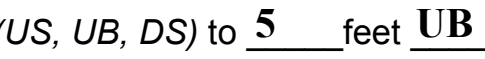

Exist? $\mathbf{N}(Y$ or $N)$

Severity

Impact Severity: 0- none to very slight; 1- Slight; 2- Moderate; 3- Severe 
18. Bridge Type: $4 / 1 \mathbf{a}$

1a- Vertical abutments with wingwalls

1 b- Vertical abutments without wingwalls

2- Vertical abutments and wingwalls, sloping embankment

Wingwalls perpendicular to abut. face

3- Spill through abutments

4- Sloping embankment, vertical wingwalls and abutments

1a with wingwalls

Wingwall angle less than $90^{\circ}$.

19. Bridge Deck Comments (surface cover variations, measured bridge and span lengths, bridge type variations, approach overflow width, etc.)

\#11: RBUS protection extends to drywall behind right abutment.

\#17: Wingwall protection exists at impact zone.

\#18: Left abutment has sloping wingwalls.

Right wingwalls extend straight back to drywall.

\section{Upstream Channel Assessment}

\begin{tabular}{|c|c|c|c|c|c|c|c|c|c|c|}
\hline \multicolumn{5}{|c|}{ 21. Bank height (BF) 22. Bank angle (BF) } & \multicolumn{2}{|c|}{ 26. \% Veg. cover (BF) } & \multicolumn{2}{|c|}{ 27. Bank material (BF) } & \multicolumn{2}{|c|}{ 28. Bank erosion (BF } \\
\hline 20. SRD & LB & RB & LB & RB & LB & RB & LB & RB & LB & RB \\
\hline 42.5 & 5.0 & & & 7.5 & 4 & 1 & 452 & 452 & $\mathbf{0}$ & $\mathbf{0}$ \\
\hline 23. Ban & & & 24. & width & 15.0 & 25. Th & eg dep & 39.0 & 9. Bed & 4 \\
\hline
\end{tabular}

30 . Bank protection type: $\quad$ LB

RB 0

31. Bank protection condition: LB $\mathrm{RB}$ -

SRD - Section ref. dist. to US face \% Vegetation (Veg) cover: 1- 0 to 25\%; 2- 26 to 50\%; 3- 51 to $75 \%$; 4- 76 to $100 \%$

Bed and bank Material: 0- organics; 1- silt / clay, < 1/16mm; 2- sand, 1/16 - 2mm; 3- gravel, 2 - 64mm;

4- cobble, 64 - 256mm; 5- boulder, > 256mm; 6- bedrock; 7- manmade

Bank Erosion: 0- not evident; 1- light fluvial; 2- moderate fluvial; 3- heavy fluvial / mass wasting

Bank protection types: 0- absent; 1- < 12 inches; 2- < 36 inches; 3- < 48 inches; 4- < 60 inches; 5- wall / artificial levee

Bank protection conditions: 1-good; 2- slumped; 3- eroded; 4- failed

32. Comments (bank material variation, minor inflows, protection extent, etc.):

\#27: Fine-grained material overlying cobble and boulder.

\#29: Ranges from boulder to gravel.

\#30: Large boulders line both banks but appear natural. 
33.Point/Side bar present? $\mathbf{N}(Y$ or $N$. if $N$ type ctrl-n pb)34. Mid-bar distance: -

35. Mid-bar width: -

36. Point bar extent: feet (US, UB) to feet (US, UB, DS) positioned $\%$ LB to $\%$ RB

37. Material: -

38. Point or side bar comments (Circle Point or Side; Note additional bars, material variation, status, etc.):

NO POINT BARS

A well vegetated bar is present $>100$ feet $U S$ on $L B$, just US of minor tributary. Bar is well developed and indicates slight shifting of stream.

39. Is a cut-bank present? $\mathbf{N}$ (Y or if $N$ type ctrl-n cb)

40. Where? (LB or $R B)$

41. Mid-bank distance: -

42. Cut bank extent: - feet (US, UB) to feet (US, UB, DS)

43. Bank damage: (1- eroded and/or creep; 2- slip failure; 3- block failure)

44. Cut bank comments (eg. additional cut banks, protection condition, etc.):

NO CUT BANKS

\section{Is channel scour present? $\mathbf{Y}$ (Y or if $N$ type ctrl-n cs) $\quad$ 46. Mid-scour distance: $\mathbf{- 8} \mathbf{~ f t}$. UB}

47. Scour dimensions: Length $\underline{\mathbf{4 0}}$ Width $\underline{\mathbf{1 5}}$ Depth : $\underline{\mathbf{1 . 5}}$ Position $\underline{\mathbf{5}} \%$ LB to $\underline{\mathbf{5 0}}$ \%RB

48. Scour comments (eg. additional scour areas, local scouring process, etc.):

Local scour caused by impact zone at left abutment.

\section{Are there major confluences? $\mathbf{N}$}

51. Confluence 1: Distance Confluence 2: Distance 52. Enters on Enters on ( $Y$ or if $N$ type ctrl-n $m c$ ) ( $L B$ or $R B)$ (LB or $R B)$

54. Confluence comments (eg. confluence name):

NO MAJOR CONFLUENCES

Minor tributary enters approximately 90 feet US on LB: 2 feet wide and 0.5 feet deep (at time of survey).

\section{Under Bridge Channel Assessment}

55. Channel restraint (BF)? LB 2 (1- natural bank; 2- abutment; 3- artificial levee)

\begin{tabular}{|c|c|c|c|c|c|c|c|}
\hline \multicolumn{2}{|c|}{ 56. Height (BF) } & \multicolumn{2}{|c|}{57 Angle (BF) } & \multicolumn{2}{|c|}{ 61. Material (BF) } & \multicolumn{2}{|c|}{ 62. Erosion (BF) } \\
\hline LB & RB & LB & $\mathrm{RB}$ & LB & RB & LB & $\mathrm{RB}$ \\
\hline 34 & & & & 2 & 7 & 7 & - \\
\hline
\end{tabular}

58. Bank width (BF) 59. Channel width (Amb) -

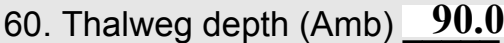
63. Bed Material -

Bed and bank Material: 0- organics; 1- silt / clay, < 1/16mm; 2- sand, 1/16 - 2mm; 3- gravel, 2 - 64mm; 4- cobble, 64 - 256mm; 5- boulder, > 256mm; 6- bedrock; 7- manmade

Bank Erosion: 0- not evident; 1- light fluvial; 2- moderate fluvial; 3- heavy fluvial / mass wasting

64. Comments (bank material variation, minor inflows, protection extent, etc.): 4

\#63: Ranges from sand to cobble. 
65. Debris and Ice Is there debris accumulation?

$(Y$ or $N)$ 66. Where? $\underline{Y}$

(1- Upstream; 2- At bridge; 3- Both)

67. Debris Potential 1 (1-Low; 2- Moderate; 3- High)

68. Capture Efficiency 1 (1-Low; 2- Moderate; 3- High)

69. Is there evidence of ice build-up? 1 (Y or N)

Ice Blockage Potential $\mathbf{N}$

(1-Low; 2- Moderate; 3- High)

70. Debris and Ice Comments:

1

Minor pile of small trees and twigs on LB upstream. Stream is moderate gradient with little bank constriction.

\begin{tabular}{|l|c|c|c|c|c|c|c|c|}
\hline Abutments & $\begin{array}{c}71 . \text { Attack } \\
\angle \text { (BF) }\end{array}$ & $\begin{array}{c}72 \text {. Slope } \angle \\
\text { (Qmax) }\end{array}$ & $\begin{array}{c}\text { 73. Toe } \\
\text { loc. (BF) }\end{array}$ & $\begin{array}{c}\text { 74. Scour } \\
\text { Condition }\end{array}$ & $\begin{array}{c}75 . \text { Scour } \\
\text { depth }\end{array}$ & $\begin{array}{c}\text { 76. Exposure } \\
\text { depth }\end{array}$ & 77. Material & 78. Length \\
\hline LABUT & & $\mathbf{5}$ & $\mathbf{9 0}$ & $\mathbf{2}$ & $\mathbf{2}$ & $\mathbf{1 . 5}$ & $\mathbf{3 . 2 5}$ & $\mathbf{9 0 . 0}$ \\
\hline RABUT & $\mathbf{1}$ & - & $\mathbf{9 0}$ & & & $\mathbf{2}$ & $\mathbf{0}$ & $\mathbf{4 2 . 5}$ \\
\hline
\end{tabular}

Pushed: $L B$ or RB

Toe Location (Loc.): 0- even, 1- set back, 2- protrudes

Scour cond.: 0- not evident; 1- evident (comment); 2- footing exposed; 3-undermined footing; 4- piling exposed; 5- settled; 6- failed

Materials: 1- Concrete; 2- Stone masonry or drywall; 3- steel or metal; 4- wood

79. Abutment comments (eg. undermined penetration, unusual scour processes, debris, etc.):

$-$

1

Left abutment - footing is raised and a subfooting exists beneath the original.

\#75: 1.5 feet scour depth $=2.5$ feet scour (surface of water) -1.0 foot thalweg

\#76: 3.25 exposure depth - footing + subfooting depths 3.0 feet and 3.5 feet

80. Wingwalls:

Exist? Material? Scour Scour Exposure $\begin{aligned} & 81 . \\ & \text { Angle? Length? }\end{aligned}$

USLWW: Condition? depth? depth?



42.5

4- wood

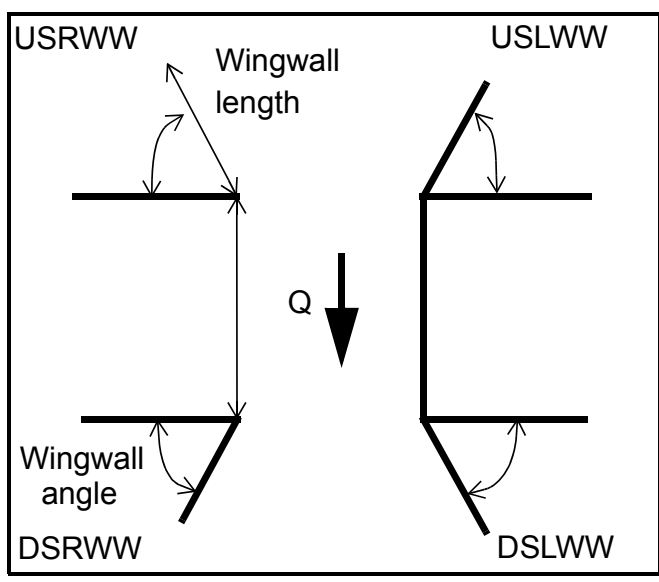

82. Bank / Bridge Protection:

\begin{tabular}{|l|l|l|l|l|l|l|l|l|}
\hline Location & USLWW & USRWW & LABUT & RABUT & LB & RB & DSLWW & DSRWW \\
\hline Type & - & $\mathbf{0}$ & $\mathbf{Y}$ & - & $\mathbf{1}$ & - & $\mathbf{1}$ & - \\
\hline Condition & $\mathbf{Y}$ & - & $\mathbf{1}$ & - & $\mathbf{1}$ & - & $\mathbf{2}$ & - \\
\hline Extent & $\mathbf{1}$ & - & $\mathbf{0}$ & $\mathbf{3}$ & $\mathbf{0}$ & $\mathbf{2}$ & $\mathbf{0}$ & - \\
\hline
\end{tabular}

Bank / Bridge protection types: 0- absent; 1- < 12 inches; 2- < 36 inches; 3- < 48 inches; 4- < 60 inches; 
83. Wingwall and protection comments (eg. undermined penetration, unusual scour processes, etc.):

$-$

$-$

$-$

$-$

0

-

0

0

\section{Piers:}

84. Are there piers? $\quad$ Pr $(Y$ or if $N$ type ctrl-n pr)

\begin{tabular}{|l|c|c|c|c|c|c|c|}
\hline $\begin{array}{l}85 . \\
\text { Pier no. }\end{array}$ & \multicolumn{3}{|c|}{ width (w) feet } & \multicolumn{3}{|c|}{ elevation (e) feet } \\
\cline { 2 - 8 } & w1 & w2 & w3 & e@w1 & e@w2 & e@w3 \\
\hline Pier 1 & & & $\mathbf{5 . 0}$ & $\mathbf{5 0 . 0}$ & $\mathbf{1 8 . 5}$ & $\mathbf{1 3 . 5}$ \\
\hline Pier 2 & & & & $\mathbf{2 0 . 0}$ & $\mathbf{1 6 . 5}$ & $\mathbf{2 5 . 0}$ \\
\hline Pier 3 & & - & - & $\mathbf{1 7 . 0}$ & - & - \\
\hline Pier 4 & - & - & - & - & - & - & w1 \\
\hline
\end{tabular}

\begin{tabular}{|l|l|l|l|l|}
\hline Level 1 Pier Descr. & \multicolumn{1}{|c|}{1} & \multicolumn{1}{|c|}{2} & 3 & 4 \\
\hline 86. Location (BF) & otec- & gside & & - \\
\hline 87. Type & tion & of & & - \\
\hline 88. Material & con- & left & & - \\
\hline 89. Shape & sists & abut & & - \\
\hline 90. Inclined? & of & ment & N & - \\
\hline 91. Attack $\angle$ (BF) & large & - & - & - \\
\hline 92. Pushed & boul- & & - & - \\
\hline 93. Length (feet) & - & - & - & - \\
\hline 94. \# of piles & ders & & - & - \\
\hline 95. Cross-members & upst & & - & - \\
\hline 96. Scour Condition & ream & & - & - \\
\hline 97. Scour depth & and & & - & - \\
\hline 98. Exposure depth & alon & & - & - \\
\hline
\end{tabular}

LFP, LTB, LB, MCL, MCM, MCR, RB, RTB, RFP

1- Solid pier, 2-column, 3- bent

1-Wood; 2-concrete; 3- metal; 4- stone

1- Round; 2- Square; 3- Pointed

Y-yes; $N$ - no

$L B$ or $R B$

0- none; 1- laterals; 2- diagonals; 3- both

0- not evident; 1- evident (comment);

2- footing exposed; 3- piling exposed;

4- undermined footing; 5- settled; 6-failed 
99. Pier comments (eg. undermined penetration, protection and protection extent, unusual scour processes, etc.):

-
-
-
-
-
-
-
-
-
-

100.

\section{E. Downstream Channel Assessment}

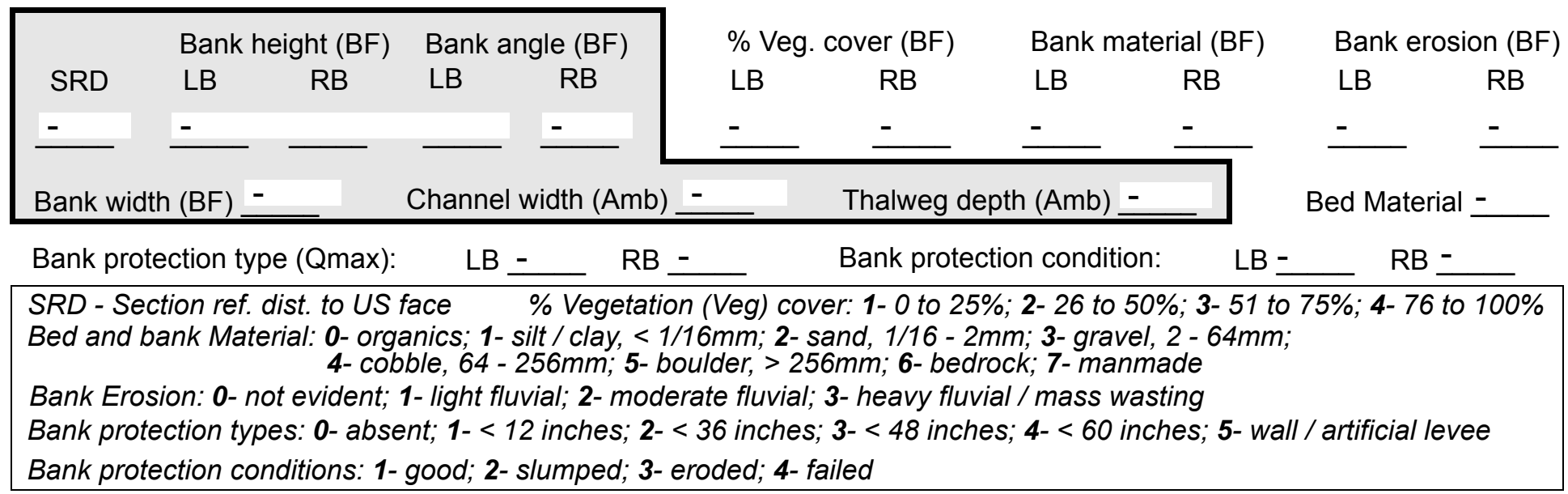

Comments (eg. bank material variation, minor inflows, protection extent, etc.):

$-$

$-$

$-$

$-$

$-$

$-$

$-$

$-$

NO PIERS

101. Is a drop structure present? ( $Y$ or $N$, if $N$ type ctrl-n $d s)$

102. Distance: - feet

103. Drop: __ feet 104. Structure material: (1- steel sheet pile; 2- wood pile; 3- concrete; 4- other)

105. Drop structure comments (eg. downstream scour depth):

4

4

452

452

2 
106. Point/Side bar present? $(Y$ or $N$. if $N$ type ctrl- $n$ pb)Mid-bar distance: 4 Mid-bar width: $\mathbf{0}$

Point bar extent: $\underline{0}$ feet -

(US, UB, DS) to feet $\underline{\mathbf{B a}}$

(US, UB, DS) DS) positioned $\mathbf{n k}$ $\%$ LB to ero \%RB

Material: sio

Point or side bar comments (Circle Point or Side; note additional bars, material variation, status, etc.):

$n$ on left bank possibly a result of eddying.

Bank material ranges from boulder to gravel.

Is a cut-bank present?

Cut bank extent: feet (Y or if $N$ type ctrl-n cb) Where? (LB or $R B)$ feet (US, UB, DS)

Bank damage: (US, UB, DS) to (1- eroded and/or creep; 2- slip failure; 3- block failure)

Cut bank comments (eg. additional cut banks, protection condition, etc.):

$\mathbf{N}$

Is channel scour present? ( $Y$ or if $N$ type ctrl-n cs)

Mid-scour distance: NO (1)

$$
\text { ( }
$$


108. Evolution comments (Channel evolution not considering bridge effects; See HEC-20, Figure 1 for geomorphic descriptors):

-

NO POINT BARS

Large anabranched island exists about $150 \mathrm{ft}$ downstream in middle of stream.

Y

LB

20

10

DS

30

DS

1 


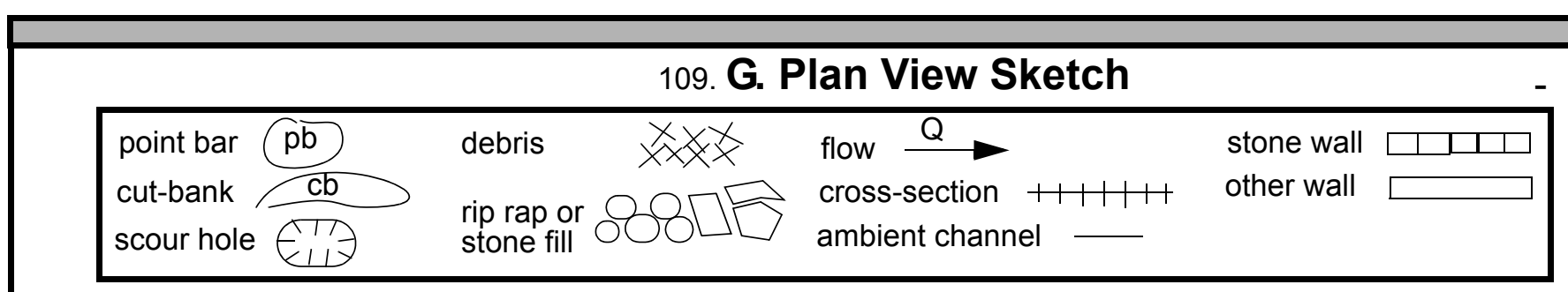


APPENDIX F:

SCOUR COMPUTATIONS 





Clear water Contraction Scour in MAIN CHANNEL

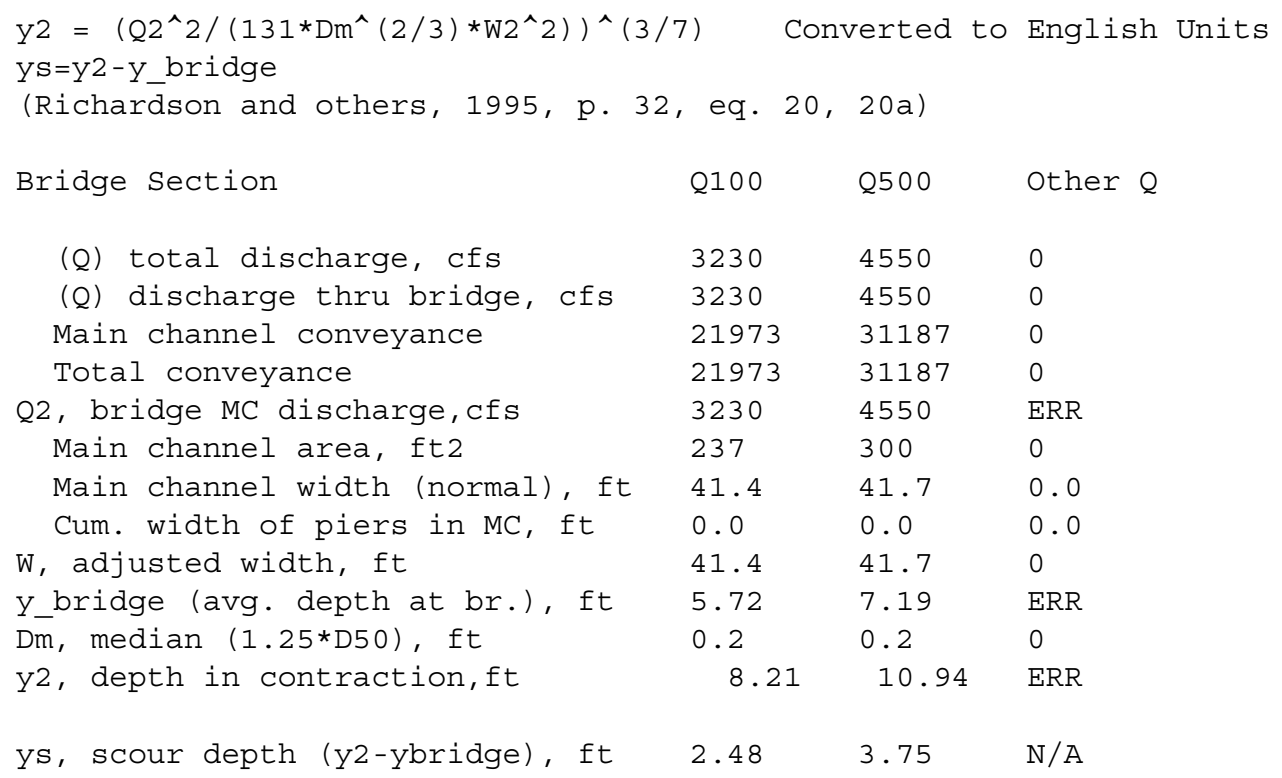

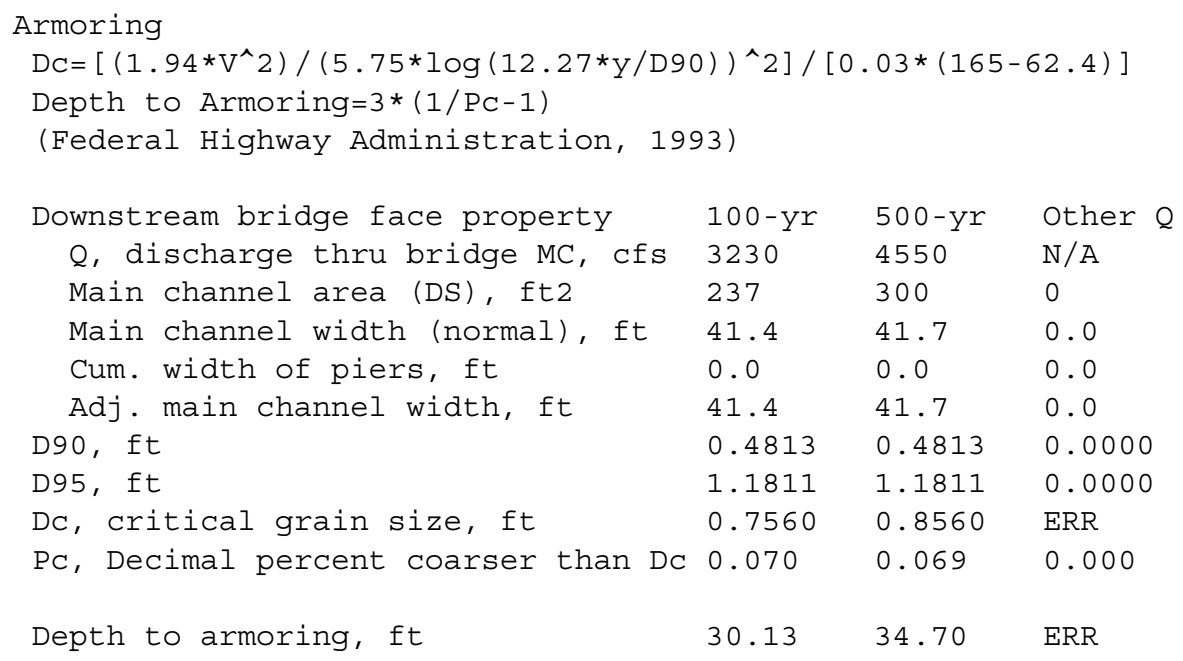


Abutment Scour

Froehlich's Abutment Scour

$\mathrm{Ys} / \mathrm{Y} 1=2.27 * \mathrm{~K} 1 * \mathrm{~K} 2 *\left(\mathrm{a}^{\prime} / \mathrm{Y} 1\right) \wedge 0.43 * \mathrm{Fr} 1 \wedge 0.61+1$

(Richardson and others, 1995, p. 48, eq. 28)

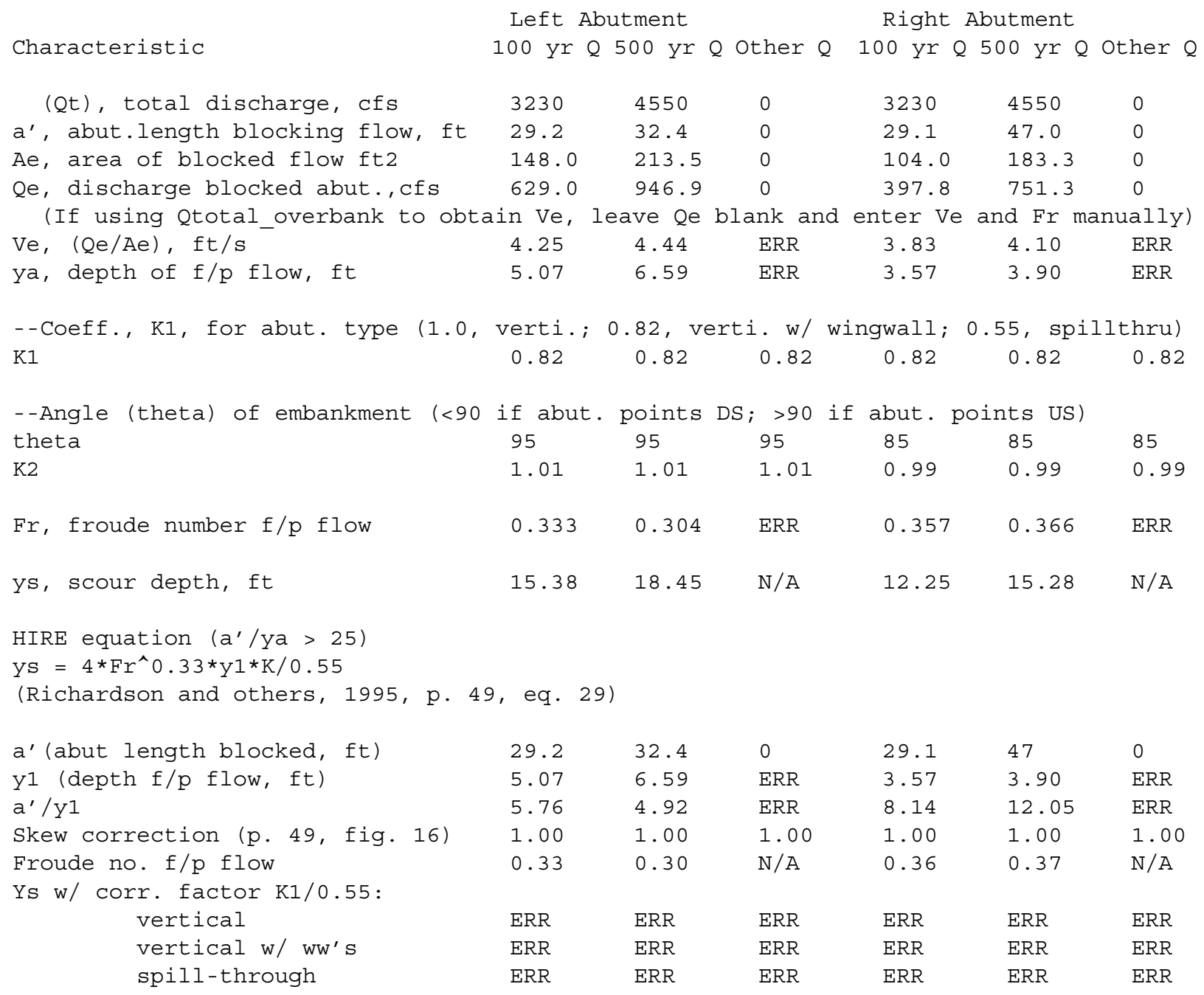




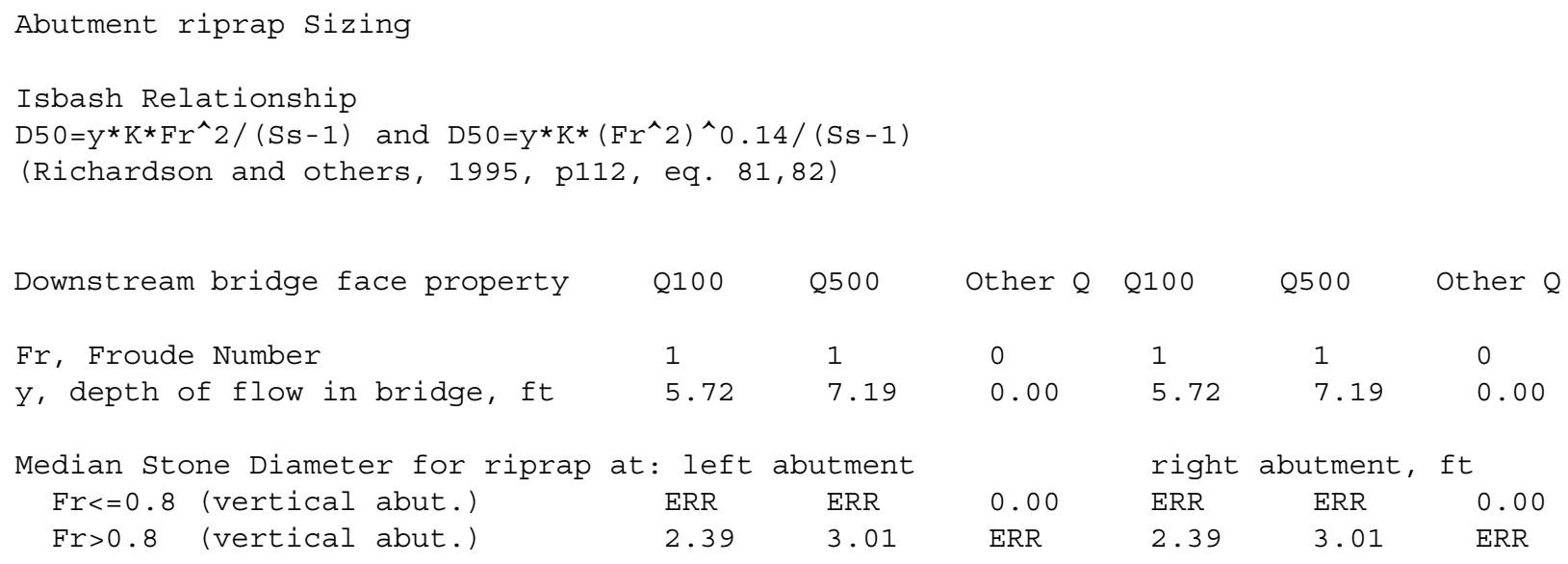

